(2) norden 



\section{Manure and energy crops for biogas production}

Status and barriers

Henrik B. Møller, Anders M. Nielsen, Marika Murto, Kjell Christensson, Jukka Rintala, Mattias Svensson, Mari Seppälä, Teija Paavola, Irini Angelidaki, and Prasad L. Kaparaju 


\section{Manure and energy crops for biogas production}

Status and barriers

TemaNord 2008:544

(C) Nordic Council of Ministers, Copenhagen 2008

ISBN 978-92-893-1696-5

Print: Ekspressen Tryk \& Kopicenter

Copies: 70

Printed on environmentally friendly paper

This publication can be ordered on www.norden.org/order. Other Nordic publications are available at www.norden.org/publications

Printed in Denmark

Nordic Council of Ministers

Store Strandstræde 18

DK-1255 Copenhagen K

Phone (+45) 33960200

Fax (+45) 33960202

www.norden.org
Nordic Council

Store Strandstræde 18

DK-1255 Copenhagen K

Phone (+45) 33960400

Fax (+45) 33111870

\section{Nordic co-operation}

Nordic cooperation is one of the world's most extensive forms of regional collaboration, involving Denmark, Finland, Iceland, Norway, Sweden, and three autonomous areas: the Faroe Islands, Greenland, and Åland.

Nordic cooperation has firm traditions in politics, the economy, and culture. It plays an important rol in European and international collaboration, and aims at creating a strong Nordic community in a strong Europe.

Nordic cooperation seeks to safeguard Nordic and regional interests and principles in the global community. Common Nordic values help the region solidify its position as one of the world's most innovative and competitive. 


\section{Contents}

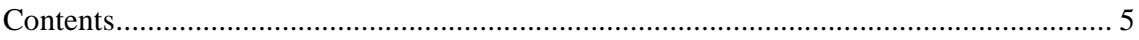

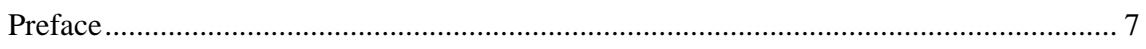

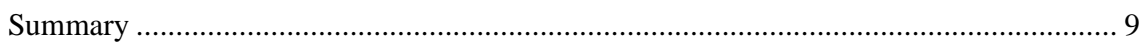

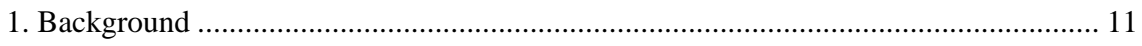

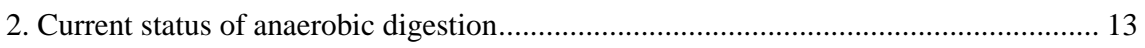

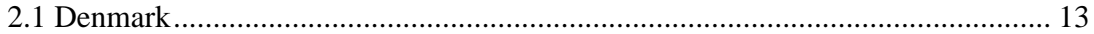

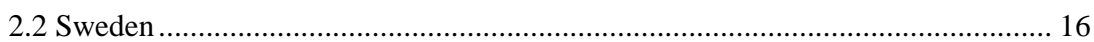

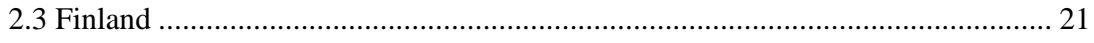

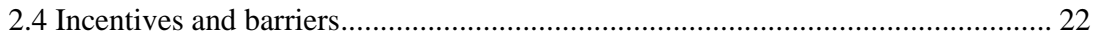

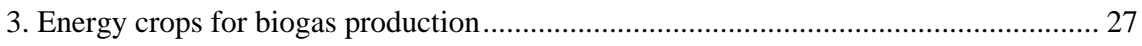

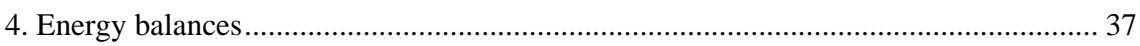

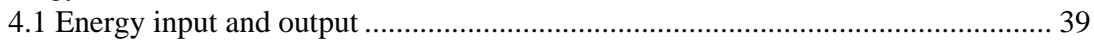

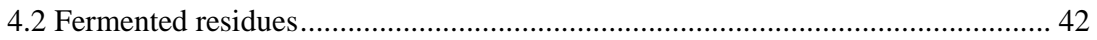

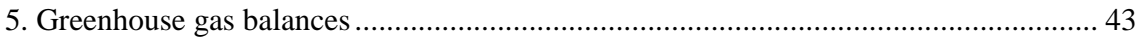

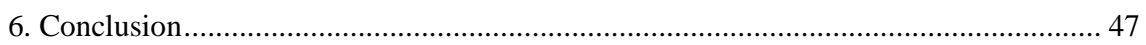

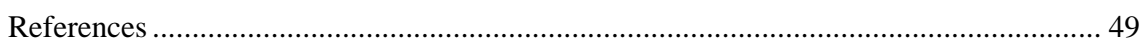

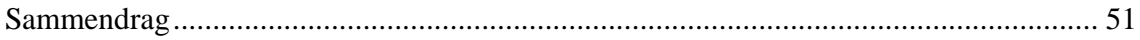





\section{Preface}

The Nordic countries and other European countries have some experience of using energy crops in biogas plants to supplement manure feedstocks. However, this knowledge has not been collected or reported, and the energy crops suitable for anaerobic digestion in one country might be less suitable in another. In 2005 University of Aarhus, Department of Agricultural Engineering, Danish Faculty of Agricultural Sciences were given the opportunity to run the project "Manure and energy crops for biogas production- Status and barriers" (2005-02) granted by Environmental Strategies in Agriculture and Forestry (MJS) in the Nordic Council of Ministers, together with partners from University of Lund, Department of Biotechnology, Department of Biology and Environmental Science Finland and Technical University of Denmark. This project compiles existing data and experience concerning the total biomass potential and yield of various crops grown in Sweden, Finland, and Denmark to supplement manure used for energy production in biogas plants. Furthermore, the project has collected information and performed calculations and analysis regarding the indirect effects on greenhouse gas emissions of growing energy crops for use as supplementary feedstocks.

Horsens, August 2007

Henrik B. Møller 



\section{Summary}

This study has evaluated the development of biogas technology in three Nordic countries and analysed the effects of using nine model energy crops in biogas plants, either alone or to supplement manure. The modelling of each crop has been based on a total balance of one hectare of land. The study compares the global warming impacts and the energy balance for the nine crops used for heat and power production. All energy input in the form of fertilizer, pesticides, diesel, lubricants for machinery were included as was the process energy used for the processing on the biogas plant. It was decided that the model used for this study is based on a biogas system where the energy crop is used as the only feedstock with a hydraulic retention time of 40 days. However the results of the energy balances of the crops can without problems be used in systems were the crops are used as a co-substrate. The methodology is the same as has been used in some other studies but few studies have looked on the total balance of one hectare of agricultural land for a range of crops. Different studies differ in the assumptions made about system design and the systems boundaries chosen. The present study has not included energy savings by substituting chemical fertilizer with the fertilizers in the digestate from the biogas plants, thus slightly underestimating the energy output compared to some other studies. On the other hand the transport, storage and spreading of digestate has not been included and it is assumed that these factors in many cases neutralize each other.

The biogas production situation and the incentives and barriers to producing biogas differ between the three countries and nine "model" crops analysed. The energy balances and impacts on greenhouse gases of the studied crops also differ between the countries. In Sweden and Denmark, the same crops turned out to be the most promising in terms of energy yield and impact on greenhouse gases. In Sweden and Denmark, Jerusalem artichoke scored the highest in terms of energy yield; however, in Finland, where only the tops of the crop are assumed to be used, the advantages of the crop do not stand out as much, though the crop is still superior to most others. In Finland, reed canary grass has produced some promising results and could be a good candidate for cultivation for biogas production. Maize and beets produce a very high energy output in all countries. In general, the same crops that score high in terms of energy yield also score high in reducing the amount of greenhouse gases.

Based on the examined parameters, it can be concluded that the most promising crops are Jerusalem artichoke, beets, maize, and, in Finland, reed canary grass as well. However, goals other than simply producing energy and reducing greenhouse gas emissions might be equally impor- 
tant. Important goals not covered in the study are low pesticide consumption, low nitrate leaching, securing clean groundwater, ability to fix nitrogen, and the ability to build soil organic matter. These goals are best achieved with perennial crops such as clover, miscanthus, and reed canary grass. 


\section{Background}

Anaerobic digestion is a simple technology that allows for decentralized energy production from various biomasses, such as animal manure, energy crops, and food industry wastes. Besides the direct effect of producing energy, anaerobic digestion has several other environmental benefits, including reduced greenhouse gas emissions. Recent analyses have identified biogas production via anaerobic digestion as one of the most costeffective strategies for greenhouse gas mitigation (Olesen et al., 2005).

Several biogas plants are in operation in the Nordic countries, where the biomass feedstock has so far mainly been animal manure and waste products. However, the energy potential of manure in terms of production volume is low and the economic performance of biogas plants relying on manure only is also low. The use of energy crops with potential for higher-volume biogas production might improve the performance of biogas plants, considerably increasing the total amount of biomass available for biogas production.

Nordic and other European countries have experience of using energy crops in biogas plants to supplement manure feedstocks, though this knowledge has not been compiled at the European level. The energy crops suitable for anaerobic digestion in one country might be less suitable in another. Furthermore, harvest and handling methods affect both the total availability and degradability of the biomass.

This project compiles existing data and experience concerning the total biomass potential and biogas yield of various crops and crop residues as supplements to manure for energy production in biogas plants. Furthermore, the project has collected available information and calculated the indirect effect on greenhouse gas emissions of growing energy crops to supplement the manure used for biogas production. The project identifies the barriers to expanding the number of biogas plants that use energy crops for biogas production. 



\section{Current status of anaerobic digestion}

Biomass is a renewable resource and, with increasing concern about global warming, will play an increasingly important role in future energy production. At the national level, renewable energy is expected to be given a high priority in efforts to reduce $\mathrm{CO}_{2}$ emissions, in accordance with the Kyoto protocol. At the EU level different targets are in effect. For example, the proportion of transport fuel supplied by biofuels in Europe is estimated to be 1\% today; however, the European Commission has set objectives of 2\% and 5.75\% for 2005 and 2010, respectively, by means of a specific directive.

Biogas production contributes to climate protection by reducing both $\mathrm{CO}_{2}$ and $\mathrm{CH}_{4}$ emissions and is expected to play an important role in achieving European Union (EU) renewable energy goals. Due to its combined advantages of preventing greenhouse gas emissions, producing energy, and reducing nitrate leaching and odour emissions from manure handling, there has been rapid growth in biogas production in recent years. In 2002, the total production of biogas in EU countries amounted to approximately 2800 ktoe (kilo tonnes oil equivalents).

The energy in biomass can be exploited by biological means, yielding various products such as biogas and bioethanol. However, the best known and most thoroughly documented technology is that of biogas production. In recent years, the performance of biogas reactors has been improved, through better control and operation of the process and improved reactor design, based on a better understanding of the process mechanisms and inhibiting factors.

\subsection{Denmark}

\section{History}

At present, the digestion of manure and organic waste is well established in Denmark, with 20 centralized plants (Figure 1) and over 57 farm-scale plants in operation. However, no new centralized plants have been established since 1998, and the development of farm-scale plants has slowed.

According to Raven and Gregersen (2005), several factors have been important for the successful implementation of biogas technology in Denmark. First, the Danish government stimulated interaction and learning between industry, farmers, municipalities, and the energy sector. 
Second, a network and long-term stimulation enabled the continuous development of biogas plants up to the late 1990s. Third, specific Danish circumstances have been beneficial, including policies promoting decentralized combined heat and electricity production (CHP), the existence of district heating systems, the imposition of energy taxes in the late 1980s, and the preference of Danish farmers for co-operating in small communities. The current setback has mainly resulted from a shift in energy and environmental policies and the limited availability of organic waste (Raven and Gregersen, 2005).

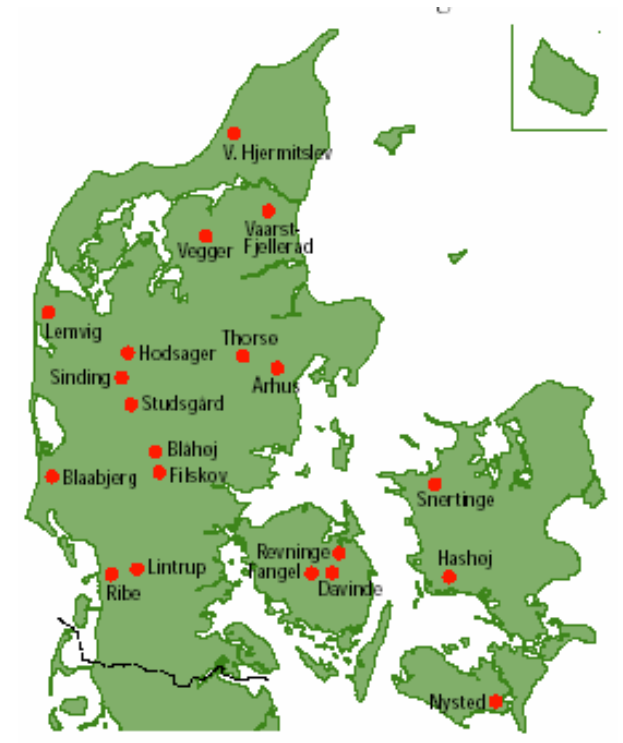

Figure 1. Co-digestion plants in Denmark. Adapted from Danish Institute of Agricultural and Fisheries Economics (1999)

Denmark has been developing centralized biogas plants since 1987; the capacities of such plants range from 50 to 500 tonnes of biomass per day. A few plants co-digest sewage sludge or the organic fraction of sourceseparated household waste as well. The resulting biogas is mainly used for combined heat and power generation, and the digested biomass is distributed to fertilize a wide range of farm crops. All the biogas plants received investment grants, ranging from $30-40 \%$ in the late 1980 s to $20 \%$ up to 2001, but today no grants are available for new plants. More than 50 farm-scale biogas plants were built from 1980 to the present, most of them co-digesting animal manure.

\section{Biomass}

Currently, Denmark produces 3.7 PJ of biogas per year (Table 1), less than 2.5 PJ coming from manure and industrial waste. A mixture of approximately $80 \%$ manure (mainly slurry) is co-digested with $20 \%$ organic wastes from food industries and municipalities. A few plants also co- 
digest sewage sludge or the organic fraction of source-separated household waste.

Table 1. Potential and realized biomass energy in Denmark (Tafdrup, 2006)

\begin{tabular}{lcr}
\hline Biomass & Potential & Realized \\
& 2006 & 2004 \\
& \multicolumn{1}{c}{ PJ } & \\
\hline Animal manure & 26.00 & 0.91 \\
Sewage sludge & 4.00 & 0.83 \\
Industrial waste, Danish & 2.50 & 0.86 \\
Industrial waste, imported & 0.00 & 0.65 \\
Meat and bone meal & 2.00 & 0.00 \\
Household waste & 2.50 & 0.03 \\
Garden waste & 1.00 & 0.00 \\
Landfill gas & 1.00 & 0.46 \\
Total & 39.00 & 3.74 \\
\hline
\end{tabular}

High-strength organic waste has so far been a pre-requisite for the economic performance of biogas plants, and the limited availability of such waste has led to its import. In the future, energy crops could offer a way to significantly increase the amount of biomass available for anaerobic digestion in biogas plants. The use of energy crops for gas production is very limited in Denmark, and only two farm-scale plants currently use energy crops. Rapeseed for biodiesel is by far the most dominant energy crop cultivated in Denmark; in addition, some woody biomass is cultivated for incineration. However, large amounts of waste straw (1 million tonnes) and wood from forests are used in the Danish energy supply.

Table 2. Examples of potential energy crops

\begin{tabular}{|c|c|c|}
\hline Crops & Energy use & Area (ha) \\
\hline Rapesęed 1 & Biodiesel & 58,555 \\
\hline Willow & Incineration & 1,501 \\
\hline Poplar $^{1}$ & Incineration & 67 \\
\hline Low forest ${ }^{1}$ & Incineration & 1,610 \\
\hline Reed canary grass ${ }^{1}$ & Incineration & 12 \\
\hline Miscanthus & Incineration & 64 \\
\hline Grass and clover $^{2}$ & Biogas & 100 \\
\hline Maize $^{2}$ & Biogas & 75 \\
\hline
\end{tabular}

${ }^{1}$ Madsen (2006)

${ }^{2}$ Estimates for four biogas plants using energy crops, located at Nimtofte (50 ha of grass as of 2006), Groengas, Thorsø, and Filskov. The total area of Danish agricultural land is 2760904 ha.

\section{Energy utilization}

All biogas produced in Denmark is used for CHP; the electricity produced is sold to the grid, while the heat produced is used for either district 
or farm heating. In some cases, the gas is sold to an energy company with a CHP plant, while in other cases the biogas plant itself owns the CHP plant.

The price of electricity delivered to the grid is fixed at EUR $0.08 / \mathrm{kWh}$ for the first ten years of production, after which it is reduced to EUR $0.05 / \mathrm{kWh}$ for the following ten years.

\subsection{Sweden}

In Sweden, biogas technology has mainly been used at wastewater treatment plants to stabilize the sewage sludge. After the energy crises of the 1970s, interest in anaerobic digestion processes increased, focusing on the production of renewable energy from other types of organic materials, such as manure and industrial wastewaters (SBGF, 2007). Anaerobic digestion technology was later applied at pulp and paper mills and sugar refineries, and small-scale plants were also constructed for treating livestock manure (Savola, 2006).

In the 1980s many plants were built to extract biogas from landfills, and since the mid 1990s a number of plants have been built to co-digest different types of organic solid waste from food industries and households (SBGF, 2007). At the same time, the development of biogas systems for vehicle fuel purposes started with Swedish government and car industry support.

The production of renewable energy, not only from organic waste, but also from dedicated energy crops, is currently being emphasized. For example, biogas plants are being built at farms on the initiative of farmers in close co-operation with municipalities and energy companies.

\section{Current situation}

In Sweden, 220 million $\mathrm{Nm}^{3}$ of biogas was produced in 2005, corresponding to an energy content of 4.63 PJ (Jarvis and Svensson, 2007). The types and numbers of plants are shown in Table 3. Most biogas is produced at plants, located at wastewater treatment plants, that digest sewage sludge. Biogas production from landfills was 1.65 PJ in 2005 and is expected to decrease, since the landfilling of organic waste is now prohibited.

A recent study estimates that the biogas production of co-digestion plants currently totals $0.59 \mathrm{PJ} /$ year and is increasing (Jarvis and Svensson, 2007); at these plants, manure is co-digested with various types of waste. The farm-based biogas plants and various pilot plants mostly digest agricultural feedstocks. 
Table 3. Biogas production in Sweden as of 2005 (Jarvis and Svensson, 2007). $1 \mathrm{TWh}=3.6 \mathrm{PJ}$

\begin{tabular}{lrr}
\hline Production type & $\begin{array}{r}\text { Number of } \\
\text { plants }\end{array}$ & \begin{tabular}{c} 
Energy production (PJ/year) \\
\hline Wastewater treatment plants
\end{tabular} 139 \\
Landfills/biocells & 70 & 2.01 \\
Industrial wastewater treatment plants & 4 & 1.65 \\
Co-digestion plants & 13 & 0.34 \\
Farm-scale plants & 7 & 0.59 \\
Total & 233 & 0.04 \\
\hline
\end{tabular}

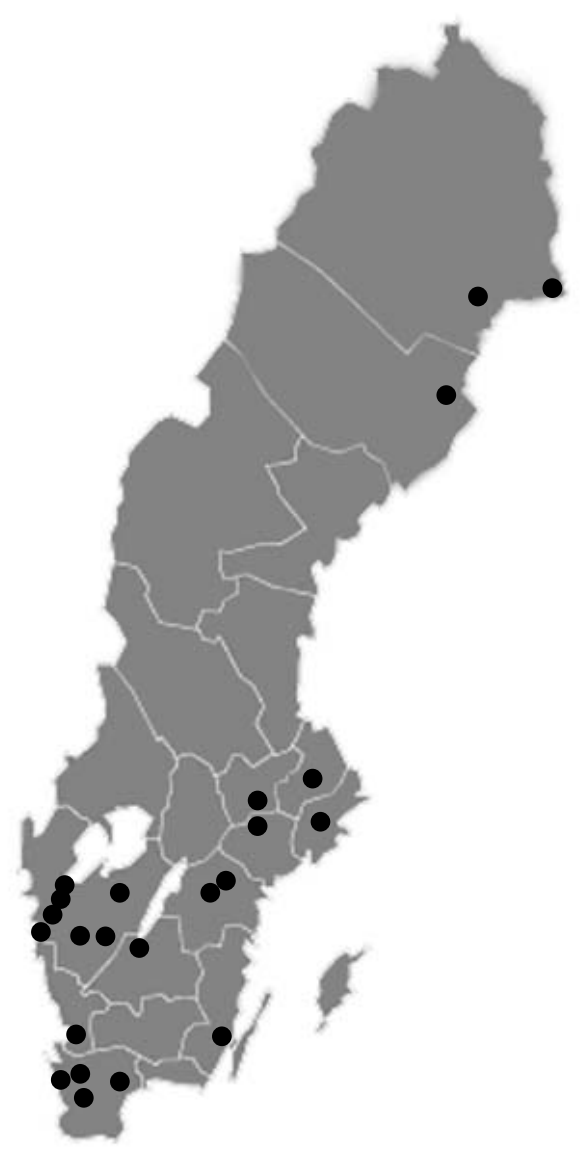

Figure 2. Full-scale biogas plants with vehicle fueling stations in Sweden (Jarvis, 2006)

\section{Utilization}

In Sweden, biogas is currently mainly used as follows: heating (33\%), internal biogas plant use (21\%), vehicle fuel (12\%), in the natural gas distribution network (2\%), flared off (9\%), and electricity production (3\%). Information about the use of the remaining $20 \%$ of the biogas produced is missing (Jarvis and Svensson, 2007). The locations of full-scale biogas plants combined with vehicle fueling stations in Sweden are shown in Figure 2 (Jarvis, 2006). At three sites, the upgraded biogas is 
injected into the natural gas distribution network. At landfills, approximately $0.07 \mathrm{PJ}(20 \mathrm{GWh})$ of biogas is used to produce electricity, while the rest is used for heating. An additional $0.25 \mathrm{PJ}(70 \mathrm{GWh})$ of biogas is flared off (Jarvis and Svensson, 2007).

\section{Vehicle fuel}

Sweden is at the forefront in using biogas as vehicle fuel, biogas corresponding to $0.57 \mathrm{PJ}$ of energy being used as vehicle fuel in 2005 and $0.45 \mathrm{PJ}$ in 2004. In comparison, 0.77 PJ of natural gas was used as vehicle fuel in 2005, which means that biogas accounted for $43 \%$ of the gaseous vehicle fuel sold (Held, 2006; SBGF, 2007). In Sweden there are 60-70 public filling stations and 23 bus filling stations selling gaseous vehicle fuel. The locations of such filling stations in southern Sweden are shown in Figure 3. There are more than 8000 gas-powered vehicles, of which approximately 930 are buses and distribution trucks. The use of gas vehicles increased by $25 \%$ and $49 \%$ in the two previous years, respectively (Held, 2006; Jarvis, 2006).

The use of biogas in the transport sector is expanding for many reasons. Above all, municipalities and industry have discovered that it is possible to earn money from a product for which there was formerly no market. The transport sector is also looking for new sources of renewable vehicle fuel. The sale of biogas is increasing, as is that of natural gas in areas where natural gas distribution infrastructure has been built. Furthermore, gas companies are taking more responsibility for biogas and are even getting involved in producing it. Consumers are demanding renewable energy and are putting pressure on gas companies to supply more of it. Biogas used as vehicle fuel is exempt from tax. For owners of biogas cars, the financial incentives include a fuel cost $20-30 \%$ lower than that of petrol, a $40 \%$ reduction of the valuation tax, and free parking in some cities (Persson, 2007).

Before being used as vehicle fuel or being injected into the natural gas distribution network, biogas must be dried and cleaned of hydrogen sulphide and other undesired materials. Furthermore, carbon dioxide must be removed to increase the calorific value of the gas. The most common upgrading techniques used in Sweden are water absorption and pressure swing adsorption (Table 4; Jönsson, 2005). The cost of upgrading biogas is approximately SEK 0.1-0.2 per kWh of cleaned gas (Persson, 2007).

A study has demonstrated that, for vehicle fuel production, the net yield per hectare of agricultural land is 55 GJ per year for biogas, when wheat including straw is used as the raw material. If ethanol is produced instead, the "draff" is used as fodder and the straw is ploughed into the soil, giving a net yield per hectare per year of 20 GJ. Producing biogas from ley crops gives a net yield of 36 GJ of vehicle fuel per hectare per year (Börjesson, 2004). 
Table 4. Biogas upgrading techniques used in Sweden (Jönsson, 2005)

\begin{tabular}{ll}
\hline Method & Number of plants \\
\hline Water absorption with regeneration & 7 \\
Water absorption without regeneration & 5 \\
Pressure swing adsorption (PSA) & 6 \\
Selexol & 1 \\
Chemical absorption & 1 \\
Total & 20 \\
\hline
\end{tabular}

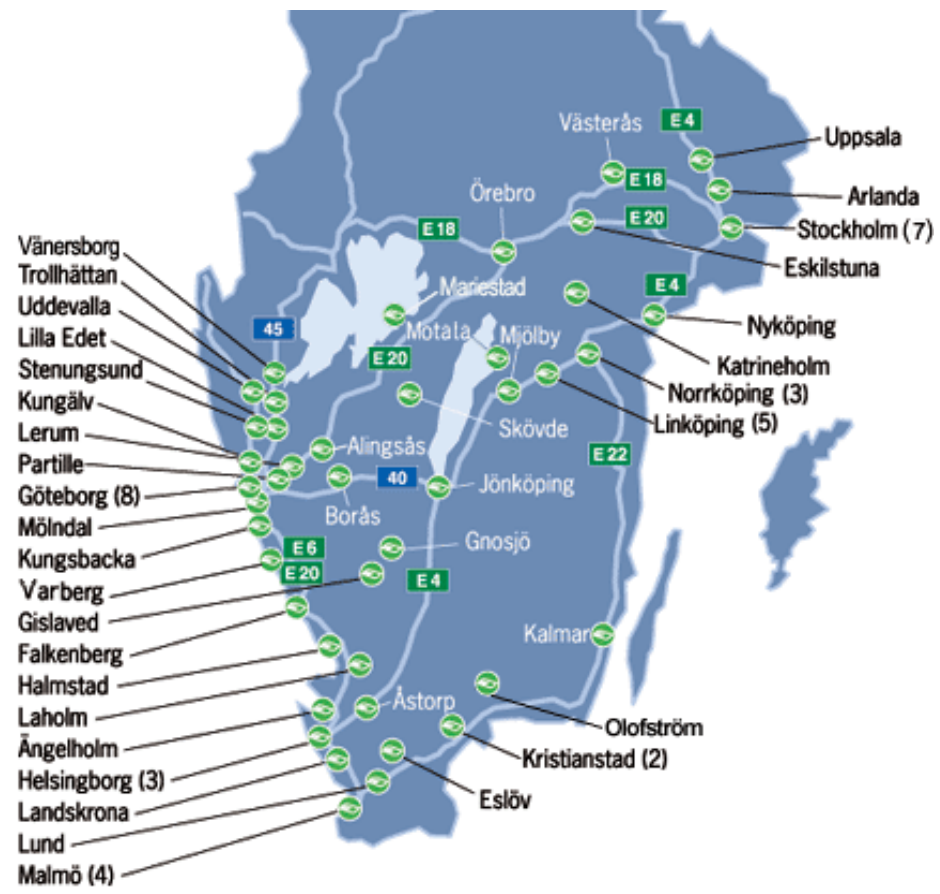

Figure 3. Gas stations in southern Sweden as of 2005 (Fordonsgas, 2006). In northern Sweden, there are fuel stations in Boden, Skellefteå, and Östersund

\section{Injection into natural gas distribution network}

It is important to be able to use all the biogas produced. Sometimes more biogas is produced than can be immediately used and the excess is flared off. One study estimated that approximately $9 \%$ of the biogas produced at biogas plants was flared off, while other data indicated that $13.5 \%$ of the biogas produced at landfills was flared off in 2004 (Held, 2006). If this biogas had been upgraded it could have been injected into the natural gas distribution network, meaning that none would have had to be flared off.

It is also important to guarantee the delivery of gas at all times, so natural gas serves as a back-up to the biogas injected into the natural gas distribution network. The gas network can also serve as a buffer storage system. Distributing the upgraded biogas via the gas network reduces the need to transport fuel to users. In Laholm, upgraded biogas is injected into the local natural gas distribution system, replacing $25 \%$ of the natural 
gas used; in Helsingborg and Gothenburg, upgraded biogas is also injected into the natural gas system (Held, 2006).

\section{Digestate}

In 2005, 251840 tons of biodigestate were produced by biogas plants; $98 \%$ of this was recycled by being spread on agricultural land, the remainder being dewatered and/or subsequently composted. The compost produced at the plants was mainly used as fertilizer or in soil mixtures (RVF, 2005).

The digestate can be certified in Sweden, which ensures to the user that the product is of good quality; with such certification, the customer can rely more on the product, and the sales prospects improve. Biogas plants that produce compost or biodigestate from sorted biowaste, including waste from food industries, can mark their product with a quality certification symbol and label it "Certifierad Återvinning" (certified reuse).

The inspecting organization responsible for the certification system is SP - Sveriges Provnings- och Forskningsinstitut (Swedish National Testing and Research Institute). Permission to use the certification symbol is granted after verification that the product fulfils the requirements set forth in a standard that covers the whole management chain from incoming waste to end use. There are seven certified biogas plants in Sweden, located at Helsingborg, Kalmar, Kristianstad, Laholm, Linköping, Uppsala, and Vänersborg (RVF, 2005; Månsson, 2006).

\section{Future potential}

In Sweden, the biogas potential has been estimated to be 50-60 PJ/year (Linné et al., 2005; Nordberg et al., 1998), agricultural feedstocks having the greatest potential. Production at wastewater treatment plants could be increased to 3.6 PJ/year, which represents just a small increase from today's levels. Household and restaurant waste, separated at source, has a biogas potential of $3.4 \mathrm{PJ} /$ year (Linné et al., 2005). Industrial organic waste could contribute $3.3 \mathrm{PJ}$, of which only approximately $10 \%$ is currently being used for biogas production (Linné et al., 2005; Nordberg et al., 1998). Organic waste from urban parks and gardens is estimated to have a potential of 1.7 PJ/year (Lantz et al., 2007).

The greatest potential, however, is found in agricultural feedstocks, which are currently almost unexploited. The biogas potential of animal manure is estimated to be $9.2 \mathrm{PJ} /$ year (Lantz et al., 2007; Linné et al., 2005), while that of crop residues, such as sugar beet tops, is estimated to be 3.5 PJ/year (Linné et al., 2005; Nordberg et al., 1998). Nordberg et al. (1998) estimated the biogas potential of straw to be approximately 25 $\mathrm{PJ} /$ year; however, later estimates have excluded straw, since it is conside- 
red to be difficult to digest (Linné et al., 2005) and hence better suited for combustion for energy recovery.

If energy crops were grown on farmland currently fallow or used for export crops, up to 600000 ha could be made available for dedicated energy crops (Herland, 2005). Linné et al. (2005) estimated the potential of energy crops for biogas to be $26 \mathrm{PJ} /$ year, assuming 260000 ha were planted in various crops. Ley crops are currently grown on 900000 ha (SCB, 2005), mainly as cattle feed but also to a lesser degree as green manure crops in organic farming.

\subsection{Finland}

Biogas has a long history in Finland, the first sewage sludge digester in the Nordic countries having been built in the 1930s in Helsinki. Nowadays, sludge digesters are used in 15 major sewage treatment plants, mainly to stabilize the excess sludge; the biogas produced is used for electricity and heat production.

After the oil crisis, in the late 1970s, interest in biogas was rapidly growing and some biogas plants were built on farms to produce energy. However, these plants stopped operation afterwards, apparently due to poor economics arising from decreasing oil prices. As early as the early 1980s it was proposed that biogas plants should be constructed along natural gas lines to supply gas to the distribution network. However, this has yet to be realized. One company active in biogas business at that time was the subsidiary of the state-owned oil company, Neste Oil.

One of the first biogas plants in the world for treating municipal solid waste (MSW) was built in 1990 in Vaasa, Finland. A second digester was built in Vaasa in the early 1990s; it operated under thermophilic conditions and was one of the first thermophilic digesters used to treat MSW. Landfill gas recovery was increasingly implemented starting in 2000 to reduce greenhouse gas emissions, and gas is now being recovered from 33 of the largest landfills. In 2005, approximately $118.4 \mathrm{Mm}^{3}$ of landfill gas was recovered, of which 53\%, corresponding to 298.5 GWh (1.07 PJ), was used.

Two co-digestion plants began operating in 2004-2005, the larger one co-digesting approximately 100000 tons of pig manure and industrial byproducts annually. As well, two co-digestion plants and four to five farmscale biogas plants are under construction. In 2005, biogas production (landfill gas not included) totalled $26.4 \mathrm{Mm}^{3}$; of this amount, $23.1 \mathrm{Mm}^{3}$ was used, 32.6 GWh (0.12 PJ) for electricity production, 89.9 GWh (0.32 $\mathrm{PJ})$ for heat production, and 2.0 GWh $(0.007 \mathrm{PJ})$ for mechanical energy production.

The first public gas fuelling stations opened in 2006, and the number (currently five) is expected to grow to $30-40$ in a few years. Farm-scale 
upgrading of biogas has been used at individual farms since 2003 to supply biofuel for the owners' own biofuel vehicles; nowadays, the farmproduced fuel is also sold to the public.

Depending on the applicable laws, enterprises and communities may get up to $30-40 \%$ and farms $15-30 \%$ grant for energy investments though such support is not always granted. No guaranteed prices are offered for electricity produced from biogas in Finland. Biogas-based vehicle fuel is, however, free of some taxes. The role of biogas is expected to increase with the increasing use of biofuels and of vehicles using gaseous fuels. Biogas potential has been evaluated in several studies, which have produced widely varying results; the results of one of the most recent evaluations are presented in Table 5.

Table 5. Biogas potential in Finland

\begin{tabular}{lccc}
\hline Biomass & Maximum potential ${ }^{\mathbf{1}}$ & $\begin{array}{c}\text { Technically feasible by } \\
\mathbf{2 0 1 5 ^ { 1 }} \\
\text { PJ }\end{array}$ & $\begin{array}{c}\text { Realized } \\
\mathbf{2 0 0 5 ^ { 2 }}\end{array}$ \\
\hline Municipal solid waste & $3.1-4.6$ & $1.9-2.8$ & $\sim 0.031$ \\
Food industries & $1.5-2.3$ & $0.8-1.2$ & $\sim 0.025$ \\
Sewage sludge & 3.1 & 0.6 & $\sim 0.5$ \\
Manure and straw & $110-490$ & $11-49$ & $\sim 0.03$ \\
Agrobiomass (fallow only) & 25 & 7.5 & $\sim 0$ \\
Landfill gas & 2.4 & 2.4 & -1.14 \\
Total & $140-530$ & $24-64$ & $\sim 1.73$ \\
\hline
\end{tabular}

${ }^{1}$ Asplund et al., 2005 http://ktm.elinar.fi/ktm jur/ktmjur.nsf/all/E5063805F1B754D5C22570190028414D/\$file/34642005.pdf

${ }^{2}$ Kuittinen et al. (2006. http://www.biokaasuyhdistys.net).

\subsection{Incentives and barriers}

Anaerobic digestion has traditionally been considered a method for treating waste, though it is now viewed as a method for producing renewable energy and combating climate change.

The potential of biogas systems is considerable at the regional level due to their positive economic, environmental, and social impacts. Regional energy systems allow individuals, organizations, and communities to establish secure, local energy supplies. Jobs and businesses are generated along as biogas infrastructure is established, as biogas systems promote the use of locally available resources and organic wastes (Savola, 2006).

The use of biogas systems can provide a way of achieving official environmental objectives. In Sweden, the government has established 16 environmental goals, eight of which can be furthered by biogas systems, for example, reducing greenhouse gas emissions, improving soil fertility, and reducing nutrient leaching to receiving waters.

The Swedish government has given investment subsidies to several municipally defined and run projects that have environmental aims. The- 
se projects mainly aim to reduce emissions of greenhouse gases at the local level, and reducing these emissions has been given the highest priority of all the environmental quality objectives. The environmental advantages of biogas systems are easier to understand from a regional than a national point of view (Savola, 2006). Many projects have aimed at combating climate change at the local level by implementing biogas systems. The most important incentives for constructing biogas plants in Sweden came from the Local Investment Programme (LIP), now replaced by the National Climate Investment Programme (KLIMP), which granted investment subsidies. These subsidies can only be applied for by municipalities or similar organizations as the main actors; however, farmers can apply in co-operation with such parties. KLIMP mainly favours large projects. Another option for farmers is investment subsidies as part of the agricultural development programme (LBU) promoting construction of farm-based biogas plants (Lantz et al, 2007).

The governmental Commission on Oil Independence has identified several factors that will contribute to decreasing fossil fuel consumption by 2020, a goal that will mainly be achieved by the use of renewable energy (Commission on Oil Independence, 2006). Sweden imposes energy and $\mathrm{CO}_{2}$ taxes on fossil fuels, taxes from which renewable fuels, including biogas, are exempted. There is also a transport biofuels directive in Sweden that sets a 5.75\% target for transport biofuels by 2010. If biogas is used for generating electricity, its producers receive one electricity certificate for each MWh produced, which they can then sell to electricity users; the average price of the certificates in the market was EUR 7/GJ in 2004 (Savola, 2006).

A policy instrument prohibiting the landfilling of organic materials encourages the development of biogas systems, though competing treatment methods are also encouraged. However, this barrier is reduced by a proposed tax on the fossil fraction of incinerated waste in order to promote, for example, material recirculation and biological treatment methods. There is an interim target within the national environmental objectives stating that $35 \%$ of municipal food waste and all non-contaminated food waste from food industries should be treated biologically by the year 2010 (Lantz et al., 2007).

There are also incentives to encourage farmers to grow energy crops. In the EU, the cultivation of energy crops is subsidized to a maximum amount of EUR 45/ha, if the crop is grown on non-set-aside land. Energy crops can also be grown on set-aside land, which can give farmers extra income. A reduced market price for food crops favours the production of energy crops (Lantz et al., 2007).

Competing waste treatment technologies are composting of sourceseparated waste and incineration (with energy recovery) of mixed waste. The main advantage of anaerobic digestion over composting is its positive energy balance. Furthermore, a life-cycle analysis demonstrated that 
all environmental impacts were reduced by replacing composting with biogas systems; this was indicated by reduced greenhouse gas emissions (by the production of $\mathrm{CO}_{2}$-neutral energy replacing fossil fuel) and by reduced eutrophication and acidification potentials arising from better nitrogen recycling (by reducing emissions) (Savola, 2006).

Waste will probably also provide the biogas producer with income from gate fees. However, the biogas producer might still need to pay for crop residues and energy crops. Manure, which does not require any additional handling by the farmer, is probably available to the biogas producer for the asking if transportation costs are covered (Lantz et al., 2007). The gate fees for a centralized biogas plant are currently higher than for delivering municipal organic waste to an incineration plant. Furthermore, since the municipal waste is separated at source it gives additional costs and therefore there are currently no economic incentives to encourage waste companies to deliver municipal organic waste to centralized biogas plants (Lantz et al, 2007). For industrial wastes, however, the gate fees at centralized biogas plants are lower than at incineration plants. In the future, increased numbers of biogas plants will increase competition, possibly leading to reduced gate fees.

One incentive to use agricultural feedstocks is the possibility of using biodigestate as a fertiliser, which would reduce the need for commercial fertiliser; this would be especially valuable for organic farmers.

Public opposition may act as a barrier to the expansion of large-scale, centralized biogas plants, due to concerns about increased transport of feedstocks and odour from the plant. It is thus crucial to involve both local authorities and members of surrounding communities in planning such plants (Khan, 2003).

One barrier to the efficient use and distribution of biogas as vehicle fuel is that it requires special fueling stations, which are a costly investment. This is the main reason for the ten-times-higher cost of the distribution infrastructure for biogas as opposed to ethanol (Savola, 2006).

Table 6. Comparison of the studied countries regarding biogas income and potentials

\begin{tabular}{|c|c|c|c|}
\hline & Denmark & Sweden & Finland \\
\hline Biogas for transport & $\begin{array}{l}\text { No tax reduction, no } \\
\text { fuelling stations }\end{array}$ & $\begin{array}{l}\text { Tax reduction, several } \\
\text { fuelling stations }\end{array}$ & $\begin{array}{l}\text { No tax, one farm-scale } \\
\text { fuelling station }\end{array}$ \\
\hline Biogas for power & $\begin{array}{l}\text { Guaranteed price of EUR } \\
0.08 / \mathrm{kWh} \text { for first ten } \\
\text { years of production, and } \\
\text { EUR } 0.05 / \mathrm{kWh} \text { for next } \\
\text { ten years }\end{array}$ & $\begin{array}{l}\text { Sale of green electrici- } \\
\text { ty certificates at EUR } \\
7 / G J(E U R \text { 0.02/kWh) }\end{array}$ & $\begin{array}{l}\text { Electricity price will be } \\
\text { guaranteed beginning } \\
\text { in 2008; price level not } \\
\text { forthcoming }\end{array}$ \\
\hline $\begin{array}{l}\text { Grants for invest- } \\
\text { ment }\end{array}$ & No grants & $\begin{array}{l}\text { Grants for biogas } \\
\text { plants and gas fuelling } \\
\text { stations }\end{array}$ & No grants \\
\hline Potentials & $\begin{array}{l}\text { Manure: } 20 \mathrm{PJ} \\
\text { Waste: } 2.5 \mathrm{PJ} \\
\text { Crops (125 } 000 \text { ha): } 18 \\
\text { PJ }\end{array}$ & $\begin{array}{l}\text { Manure: } 9.2 \mathrm{PJ} \\
\text { Waste: } 8.4 \mathrm{PJ} \\
\text { Crops }(260000 \mathrm{ha}): \\
26 \mathrm{PJ}\end{array}$ & $\begin{array}{l}\text { Manure: } 15.5 \text { PJ } \\
\text { Crops } \\
\text { (500 000 ha): } 54 \text { PJ } \\
\text { (KTM, 2007) }\end{array}$ \\
\hline
\end{tabular}


In all countries there is great potential for producing energy from manure, waste, and crops, only minor parts of which are used today.

There are different barriers and incentives in Sweden, Denmark, and Finland to introducing biogas in the transport sector (Table 6). In Sweden, biogas use in the transport sector has been encouraged, so there are 60-70 public biogas fuelling stations. Moreover, biogas used as a vehicle fuel is exempted from tax and there is free parking in some cities for cars running on biogas; the same incentives are not present in the other countries. Only exempting biogas from tax in the transport sector will allow this energy source to compete with fossil fuel.

There are also different barriers to producing electricity from biogas; in Finland, for example, a guaranteed price for biogas-generated electricity will not be introduced before 2008. In contrast, Sweden offers green certificates for sale for EUR 0.02/kWh, while Denmark guarantees a price of EUR $0.08 / \mathrm{kWh}$ for the first ten years of biogas-produced electricity and EUR $0.05 / \mathrm{kWh}$ for the next ten years. Thus the incentives for producing power from biogas are best in Denmark. 



\section{Energy crops for biogas production}

In the past, efforts were concentrated on the intensive production of food on arable land. However, in the future some arable land resources may be used for energy farming, with cultivation systems aiming at high energy output. Conversion of energy crops in biogas plants might offer a very attractive way to produce energy from a range of energy crops. From the perspective of an increased future use of energy crops, there is a need for detailed investigation of the effects of adding energy crops to biogasplants and optimizing the process in existing and future biogas plants. However, practical experience with the digestion of energy crops is lacking and has not been gathered together; hence, data describing the potentials and limitations of energy crops for digestion in biogas plants must be compiled.

All agricultural crops and crop residues can in theory be used for biogas production. However, if the lignin content is too high, appropriate pre-treatment is necessary to exploit the full energy potential via anaerobic digestion. Potential energy crops can be divided into several main categories (Table 7).

Table 7. Main categories of potential energy crops

\begin{tabular}{llll}
\hline Annual crops & 2-3-year crops & Permanent crops & Crop residues \\
\hline Cereals: & Silage: & Perennial grass & Straw from cereals \\
Wheat & Clover & Miscanthus & Beet tops \\
Triticale & Alfalfa & & \\
Silage: & Jerusalem artichoke & & \\
Sugar/fodder beet & Hemp & & \\
Maize & & & \\
Sunflower & & & \\
\hline
\end{tabular}

Table 7 shows some typical crops suitable for producing biogas feedstocks. The methane yields of the crops depends on the sort of crop, harvesting time, harvesting method, and conservation technology. Furthermore, the practically obtained yield also depends on the biogas process technology, type of reactor, and mode of operation. There is always a compromise between the treatment time and the residence time of the substrate in the reactor, a shorter residence time giving a lower methane yield.

Several parameters must be considered when choosing the most appropriate crops for methane production, the most important being: 
1. High biomass yield

2. High digestibility in biogas plants

3. Low energy, nutrient, and pesticide inputs

4. Low cultivation costs

5. Low harvest and storage costs

A range of crops could be used in biogas plants. From a discussion of the pros and cons of various crops, nine specific crops have been selected as the most promising. The potentials and limitations of each crop will be addressed in terms of both actual measured yield and environmental impacts; the identified crops are:

- $\quad$ Maize (Zea spp.)

- Beets (Beta vulgaris)

- Clover (Trifolium spp.)

- Triticale (X Triticosecale)

- Reed canary grass (Phalaris spp.)

- Elephant grass (Miscanthus spp.)

- Wheat (Triticum spp.)

- Hemp (Cannabis spp.)

- Jerusalem Artichoke (Helianthus tuberosus)

To assess the potential of a crop for use in a biogas plant, it is necessary to know its methane yield. The theoretical $\mathrm{CH}_{4}$ production $\left(B_{\mathrm{u}}\right)$ in terms of VS (volatile solids) can be calculated from Bushwell's formula. In practice, only part of the theoretical yield can be reached; under optimal process conditions, the practical yield is termed as the ultimate yield $\left(\mathrm{B}_{0}\right)$. The practical yield however is often lower than the ultimate yield and is, among other factors, determined by the retention time of the energy crop in the digester.

However, $B_{0}$ values have not been determined for all crops and when no batch digestion data are available for a crop, the yield can be estimated by means of a traditional feed analysis using the digestibility of its carbohydrate, lipid, and protein contents; however, the digestibility obtained by feed analysis (ultimate-feed $B_{0}$ ) will generally be lower than that obtained by biogas analysis (ultimate biogas $\mathrm{B}_{0}$ ).

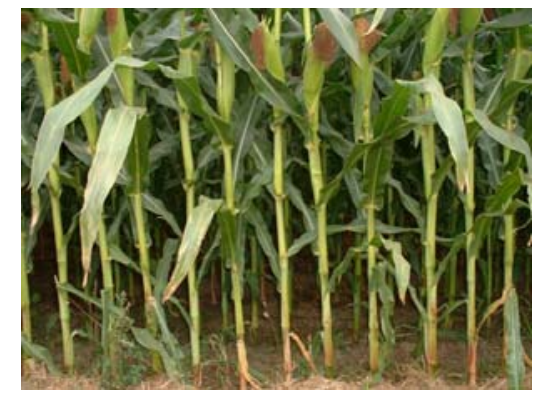

Maize

Latin: Zea spp.; English: maize, corn; Danish: majs

Maize is a cereal grain cultivated throughout the world. By weight, more maize is produced each year than any other grain in the world. Some species of maize can reach a 
height of up to 7 meters, but the maize used for commercial purposes reaches only approximately 2.5 meters. The root system of maize is quite shallow.

Table 8. Estimated dry matter yield and fertilizer consumption of maize under different conditions in the studied countries

\begin{tabular}{|c|c|c|c|c|c|c|}
\hline \multirow[b]{2}{*}{ Yield in $\mathrm{kg} \mathrm{DM}$ * $\mathrm{ha}^{-1}$} & \multicolumn{2}{|c|}{ Denmark } & \multicolumn{2}{|c|}{ Sweden } & \multicolumn{2}{|c|}{ Finland } \\
\hline & $8995^{1}$ & $11244^{2}$ & 11000 & $17000^{3}$ & $9000^{4}$ & $12000^{4}$ \\
\hline VS $\%$ of DM & \multicolumn{2}{|c|}{96} & \multicolumn{2}{|c|}{96} & \multicolumn{2}{|c|}{96} \\
\hline $\begin{array}{l}\text { N/P/K applied kg * } \\
\mathrm{ha}^{-1}\end{array}$ & \multicolumn{2}{|c|}{$146 / 42 / 111$} & \multicolumn{2}{|c|}{$180 / 27 / 95$} & & \\
\hline Yield of $\mathrm{CH}_{4}$ & \multicolumn{4}{|c|}{$0.36 \mathrm{Nm}^{3} * \mathrm{~kg} \mathrm{VS}^{-1}$} & & \\
\hline
\end{tabular}

${ }^{1}$ Sandy soil in Denmark (Landscenteret, 2006)

${ }^{2}$ Loamy soil in Denmark (Landscenteret, 2006)

${ }^{3}$ Yield in Götaland, southern Sweden (Svenska majs AB, 2006)

${ }^{4}$ Yield in southern Finland (data not published)

The biogas yield of maize has been determined in various studies in Austria and Denmark: Amon et al. (2007) found a yield of 268-366 L CH$/ \mathrm{kg}$ VS, Møller (2007) found a yield of 360-390 $\mathrm{L} \mathrm{CH}_{4} / \mathrm{kg}$ VS, and Jarvis and Svensson (2007) found a yield of $0.40-0.45 \mathrm{Nm}^{3} \mathrm{CH}_{4} / \mathrm{kg} \mathrm{VS}$ (at $25^{\circ} \mathrm{C}$ ) at late harvest. Kreuger and Björnsson (2006) reported a methane yield of $0.32 \mathrm{Nm}^{3} * \mathrm{~kg} \mathrm{VS}^{-1}$ with a digestion time of 55 days in a lab-scale experiment; furthermore, a methane yield of $0.29 \mathrm{Nm}^{3} * \mathrm{~kg} \mathrm{VS}^{-1}$ was obtained in a two-stage pilot process.

The reason for the different yields is probably that the batch digestion process used in the Austrian study was only 42 days, while in the Danish study it was 105 days. In calculating energy balances, a yield under optimal conditions is set to $0.36 \mathrm{Nm}^{3} * \mathrm{~kg} \mathrm{VS}^{-1}$.

\section{Elephant Grass}

Latin: Miscanthus giganteus; English: elephant grass, e-grass; Danish: elefantgræs

Miscanthus is a perennial grass that can reach a height of more than 3 meters. A hybrid of two Miscanthus spp. resulted in the Miscanthus giganteus often used as an energy crop.

Miscanthus can grow in a cool climate like that of Northern Europe and is excellent at utilizing available light, water, and nitrogen. It is popularly called "elephant grass" even though it is not the true elephant grass.

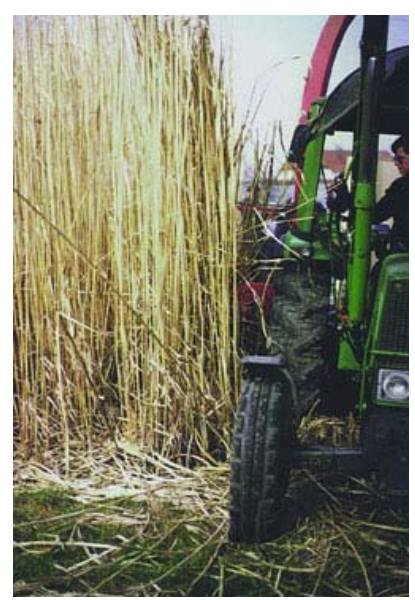
It is a C4 plant. 
Table 9. Estimated dry matter yield and fertilizer consumption of Miscanthus giganteus under different conditions in the studied countries

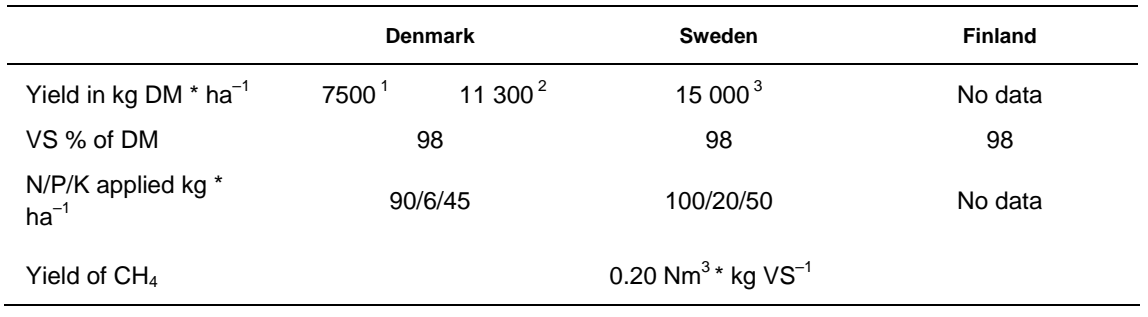

${ }^{1}$ Sandy soil in Denmark (Graversen and Gylling, 2002)

${ }^{2}$ Loamy soil in Denmark (Graversen and Gylling, 2002)

${ }^{3}$ Loamy soil in Sweden; not commercially grown in Sweden (Christensson et al., 1997)

The biogas yield of Miscanthus giganteus has only been determined in a few cases. In 2007, the Faculty of Agricultural Science, University of Aarhus, initiated some experiments. The preliminary results of this study indicate that it is possible to have a yield of $200 \mathrm{~L} \mathrm{CH}_{4} / \mathrm{kg}$ VS if harvest is in September, while later harvest will reduce the specific methane yield; however, harvest in September will probably reduce the total dry matter yield compared to that obtained by later harvest.

Beets

Latin: Beta vulgaris; English: beets;

Beets are an important food crop and come in several cultivated varieties, such as fodder and sugar beets. Cultivated Beta vulgaris is harvested annually, even though it is actually a biennial.

Beet leaves are heart shaped and may reach a considerable length. Beets are

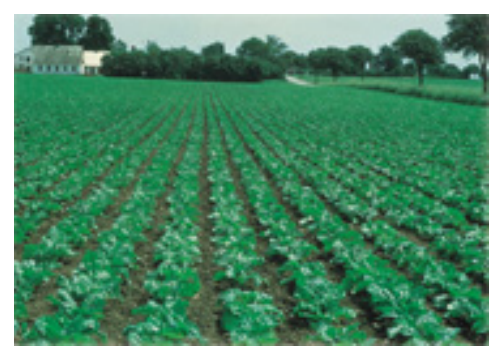
easily cultivated and grow very well, although considerable labour in required to cultivate beets at a large scale.

Table 10. Estimated dry matter yield and fertilizer consumption of Beta vulgaris under different conditions in the studied countries

\begin{tabular}{|c|c|c|c|c|c|c|}
\hline \multirow{3}{*}{ Yield in $\mathrm{kg} \mathrm{DM}$ * $\mathrm{ha}^{-1}$} & \multicolumn{2}{|c|}{ Denmark } & \multicolumn{2}{|c|}{ Sweden } & \multicolumn{2}{|c|}{ Finland } \\
\hline & $10000^{1}$ & $13000^{2}$ & \multirow{2}{*}{$10000^{3}$} & \multirow{2}{*}{$11000^{3}$} & $6300^{4}$ & $9600^{5}$ \\
\hline & $3000^{a}$ & $3900^{a}$ & & & $2500^{c}$ & $3200^{c}$ \\
\hline VS $\%$ of DM & \multicolumn{2}{|c|}{92} & \multicolumn{2}{|c|}{92} & \multicolumn{2}{|c|}{92} \\
\hline $\begin{array}{l}\text { N/P/K applied kg * } \\
\mathrm{ha}^{-1}\end{array}$ & \multicolumn{2}{|c|}{$172 / 40 / 312$} & \multicolumn{2}{|c|}{$120 / 20 / 38$} & \multicolumn{2}{|c|}{$140 / 80 / 180$} \\
\hline Yield of $\mathrm{CH}_{4}$ & \multicolumn{6}{|c|}{$0.38 \mathrm{Nm}^{3} * \mathrm{~kg} \mathrm{VS}^{-1}$} \\
\hline
\end{tabular}

${ }^{1}$ Sandy soil in Denmark (Landscenteret, 2006); ${ }^{\text {a }}$ Estimated yield of beet tops

${ }^{2}$ Loamy soil in Denmark (Landscenteret, 2006); ${ }^{a}$ Estimated yield of beet tops

${ }^{3}$ Southern Sweden (Christensson et al., 1997)

${ }^{4}$ Mid Finland (Research Centre of Sugar Beet, 2006); ${ }^{\mathrm{C}}$ Estimated yield of beet tops approximately $2 / 3$ of fresh root yield

${ }^{5}$ Yield in southern Finland (Research Centre of Sugar Beet, 2006); ${ }^{\mathrm{C}}$ Estimated yield of beet tops approximately 2/3 of

fresh root yield 
The harvest yields reported for Sweden are for sugar beets. However, for new varieties of fodder beets, which will be of interest for dedicated energy production, a more than $10 \%$ higher harvest yield can be expected.

When cultivating beets for energy production, both tops and roots are of interest; both are expected to have very high digestibility, and the methane yield is assessed as $0.380-0.450 \mathrm{Nm}^{3} * \mathrm{~kg} \mathrm{VS}^{-1}$ (Lehtomäki, 2006). A methane yield of $0.37 \mathrm{~m}^{3} * \mathrm{~kg} \mathrm{VS}^{-1}$ from beet tops alone has been reported (Björnsson, 2002).

\section{Clover}

Latin: Trifolium spp.; English: clover; Danish: kløver

Clover is widely used as a fodder plant for livestock in the Northern Hemisphere where it grows in a wide range of soils and climates. The most commonly grown species are white

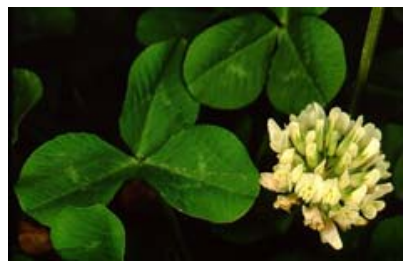
clover and red clover. It is often cultivated in mixed plantings with ryegrass.

In Finland, clover is cultivated in mixed plantings with timothy grass (Phleum pratense) and meadow fescue (Festuca pratensis). Pure clover fields are not optimal from a farmer's perspective. As a legume, clover can advantageously be used in crop rotation.

Table 11. Estimated dry matter yield and fertilizer consumption of clover grass under different conditions in the studied countries

\begin{tabular}{|c|c|c|c|c|c|c|}
\hline \multirow[b]{2}{*}{ Yield in $\mathrm{kg} \mathrm{DM}$ * ha ${ }^{-1}$} & \multicolumn{2}{|c|}{ Denmark } & \multicolumn{2}{|c|}{ Sweden } & \multicolumn{2}{|c|}{ Finland $^{\mathrm{a}}$} \\
\hline & $8091^{1}$ & $9170^{2}$ & $7000^{3}$ & $9000^{4}$ & $8000^{5}$ & $9900^{6}$ \\
\hline VS $\%$ of DM & \multicolumn{2}{|c|}{90} & \multicolumn{2}{|c|}{90} & \multicolumn{2}{|c|}{90} \\
\hline$\underset{1}{\mathrm{~N} / \mathrm{P} / \mathrm{K} \text { applied kg * ha }}$ & \multicolumn{2}{|c|}{$100 / 37 / 270$} & \multicolumn{2}{|c|}{$0 / 20 / 100$} & \multicolumn{2}{|c|}{$130 / 30 / 130$} \\
\hline Yield of $\mathrm{CH}_{4}$ & \multicolumn{6}{|c|}{$0.35 \mathrm{Nm}^{3} * \mathrm{~kg} \mathrm{VS}^{-1}$} \\
\hline
\end{tabular}

${ }^{1}$ Sandy soil in Denmark (Landscenteret, 2006)

${ }^{2}$ Loamy soil in Denmark (Landscenteret, 2006)

${ }^{3}$ Northern Sweden (Christensson et al., 1997)

${ }^{4}$ Southern Sweden (Christensson et al., 1997)

${ }^{5}$ Mid Finland (Kangas et al., 2006)

${ }^{6}$ Southern Finland (Kangas et al., 2006)

${ }^{a}$ The yields are for a mixture of $20 \%$ clover, $50 \%$ timothy, and $30 \%$ meadow fescue

In the case of clover grass, the yield in terms of both dry matter and methane yield is highly dependent on the frequency and timing of cutting. Furthermore, the amount of fertilizer, especially of potassium, is important. Because the timing of cutting varies, the specific methane yields vary between different experiments. Møller (2007), for example, found a yield of $0.31-0.42 \mathrm{Nm}^{3} * \mathrm{~kg} \mathrm{VS}^{-1}$, and in the energy balances the yield was assessed as $0.35 \mathrm{Nm}^{3} * \mathrm{~kg} \mathrm{VS}^{-1}$. Lehtomäki and Björnsson (2006) obtained a methane yield of $0.37-0.39 \mathrm{~m}^{3} * \mathrm{~kg} \mathrm{VS}^{-1}$ when grass silage of 
50\% English ryegrass (Lolium perenne) and 50\% white clover (Trifolium repens) was digested at the lab and the pilot scales, respectively.

\section{Triticale}

Latin: Triticosecale; English: triticale; Danish: triticale

Triticale is an artificial hybrid between rye and wheat. It has characteristics of both wheat and rye, but is mainly used as livestock feed. Most commercially available triticale is a second-

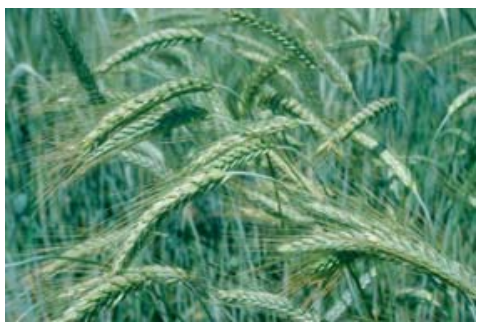
generation hybrid of different kinds of triticale. The grains of triticale are significantly larger than those of wheat.

Table 12. Estimated dry matter yield and fertilizer consumption of triticale under different conditions in the studied countries

\begin{tabular}{|c|c|c|c|c|c|c|}
\hline \multirow[b]{2}{*}{ Yield in $\mathrm{kg} \mathrm{DM}$ * $\mathrm{ha}^{-1}$} & \multicolumn{2}{|c|}{ Denmark } & \multicolumn{2}{|c|}{ Sweden } & \multicolumn{2}{|c|}{ Finland } \\
\hline & $7100^{1}$ & $9900^{2}$ & $8000^{3}$ & $10000^{3}$ & $6000^{4}$ & $7000^{5}$ \\
\hline VS $\%$ of DM & \multicolumn{2}{|c|}{95} & \multicolumn{2}{|c|}{95} & \multicolumn{2}{|c|}{95} \\
\hline $\begin{array}{l}\text { N/P/K applied kg * } \\
\mathrm{ha}^{-1}\end{array}$ & \multirow{2}{*}{\multicolumn{2}{|c|}{$135 / 23 / 70$}} & \multicolumn{2}{|c|}{$150 / 20 / 38$} & \multirow{2}{*}{\multicolumn{2}{|c|}{$130 / 20 / 50$}} \\
\hline Yield of $\mathrm{CH}_{4}$ & & & \multicolumn{2}{|c|}{$0.28 \mathrm{Nm}^{3} * \mathrm{~kg} \mathrm{VS}^{-1}$} & & \\
\hline
\end{tabular}

${ }^{1}$ Sandy soil in Denmark (Graversen and Gylling, 2002)

${ }^{2}$ Loamy soil in Denmark (Graversen and Gylling, 2002)

${ }^{3}$ Götaland and southern Svealand (Christensson et al., 1997)

${ }^{4}$ Mid Finland (Tike, 2006)

${ }^{5}$ Southern Finland (Tike, 2006)

There is little experience of using triticale for biogas production. The best biogas results are thought to be obtained when triticale is harvested green, as silage, before ripeness. Feed analysis indicates that the expected methane yield is approximately $0.28 \mathrm{Nm}^{3} * \mathrm{~kg} \mathrm{VS}^{-1}$.

\section{Reed canary grass}

Latin: Phalaris spp.; English: reed canary grass, red canary grass; Danish: rørgræs.

Reed canary grass is a tall, erect grass with a hairless stem. It reaches a height of almost 2 meters. It is grown commercially for bird seed, hence its common name. It has been suggested that canary grass should be used as human food; however, its nutritional value has not yet been fully investigated, although it is well-known to be rich in essential amino acids. Reed canary grass is considered well adapted to cold areas.

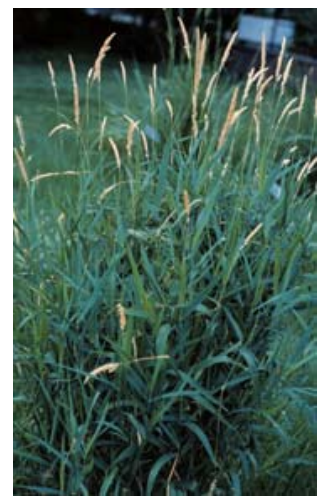


Table 13. Estimated dry matter yield and fertilizer consumption of reed canary grass under different conditions in the studied countries

\begin{tabular}{|c|c|c|c|c|c|c|}
\hline \multirow[b]{2}{*}{ Yield in $\mathrm{kg} \mathrm{DM}$ * $\mathrm{ha}^{-1}$} & \multicolumn{2}{|c|}{ Denmark } & \multicolumn{2}{|c|}{ Sweden } & \multicolumn{2}{|c|}{ Finland } \\
\hline & $5000^{1}$ & $8000^{2}$ & $5000^{3}$ & $6000^{3}$ & $7800^{4}$ & $14500^{4}$ \\
\hline VS $\%$ of DM & \multicolumn{2}{|c|}{96} & \multicolumn{2}{|c|}{96} & \multicolumn{2}{|c|}{96} \\
\hline $\begin{array}{l}\mathrm{N} / \mathrm{P} / \mathrm{K} \text { applied kg * } \\
\mathrm{ha}^{-1}\end{array}$ & \multicolumn{2}{|c|}{$50 / 30 / 30$} & \multicolumn{2}{|c|}{ 100/25/100 } & \multicolumn{2}{|c|}{$130 / 30 / 130$} \\
\hline Yield of $\mathrm{CH}_{4}$ & \multicolumn{6}{|c|}{$0.30 \mathrm{Nm}^{3 *} \mathrm{~kg} \mathrm{VS}^{-1}$} \\
\hline
\end{tabular}

Several studies of the biogas potential of reed canary grass have been conducted in Denmark and Finland. Møller et al. (2007) determined the yield to be $0.30 \mathrm{Nm}^{3} * \mathrm{~kg} \mathrm{VS}^{-1}$ for a first cut in June, dropping slightly to $0.28 \mathrm{Nm}^{3} * \mathrm{~kg} \mathrm{VS}^{-1}$ when the first cut is in July.

In Finland and Sweden, reed canary grass is cultivated mainly for incineration. Some methane production experiments using fresh silage have been performed in Finland. Reed canary grass was harvested twice a year at two different maturity stages in the summer. The methane yield of samples from the first harvest at the early flowering stage was $0.34-0.36$ $\mathrm{Nm}^{3} * \mathrm{~kg} \mathrm{VS}^{-1}$ and from the second harvest at the vegetative stage was $0.20-0.28 \mathrm{Nm}^{3} * \mathrm{~kg} \mathrm{VS}^{-1}$. The biomass dry matter yield per hectare was higher from the first than the second harvests (no fertilization). However, because of the higher TS yield when harvesting twice per year at a greater (i.e., vegetative stage) than a lesser degree of maturity (i.e., generative and flowering stage), the methane yield per hectare was also higher when harvesting later (Paavola et al., 2007).

\section{Wheat}

Latin: Triticum spp; English: wheat; Danish: hvede.

Wheat is a grass of high nutritional value cultivated worldwide for more than 9000 years. The highest per capita consumption of wheat is in Denmark. Wheat offers a good yield per unit area and grows well in a temperate climate

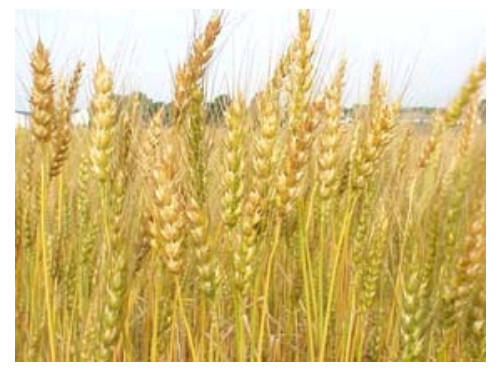
like that of Northern Europe. The flour produced is widely used for baking but is also used in a range of other food products. Wheat is the second-ranking cereal crop in terms of total production. 
Table 14. Estimated dry matter yield and fertilizer consumption of wheat under different conditions in the studied countries

\begin{tabular}{|c|c|c|c|c|c|c|}
\hline \multirow[b]{2}{*}{ Yield in $\mathrm{kg} \mathrm{DM}$ * $\mathrm{ha}^{-1}$} & \multicolumn{2}{|c|}{ Denmark } & \multicolumn{2}{|c|}{ Sweden } & \multicolumn{2}{|c|}{ Finland } \\
\hline & $4800^{1}$ & $8000^{2}$ & $7000^{3}$ & $9000^{4}$ & $3100^{5}$ & $5000^{6}$ \\
\hline VS $\%$ of DM & \multicolumn{2}{|c|}{98} & \multicolumn{2}{|c|}{98} & \multicolumn{2}{|c|}{98} \\
\hline $\begin{array}{l}\text { N/P/K applied kg * } \\
\text { ha }^{-1}\end{array}$ & \multicolumn{2}{|c|}{$140 / 28 / 94$} & \multicolumn{2}{|c|}{$180 / 20 / 50$} & \multicolumn{2}{|c|}{$110 / 25 / 150$} \\
\hline Yield of $\mathrm{CH}_{4}$ & \multicolumn{6}{|c|}{$0.43 \mathrm{Nm}^{3} * \mathrm{~kg} \mathrm{VS}^{-1}$} \\
\hline
\end{tabular}

${ }^{1}$ Sandy soil in Denmark (Landscenteret, 2006)

${ }^{2}$ Loamy soil in Denmark (Landscenteret, 2006)

${ }^{3}$ Southern Sweden (Christensson et al., 1997)

${ }^{4}$ Mid Sweden (Christensson et al., 1997)

${ }^{5}$ Mid Finland (Tike, 2006)

${ }^{6}$ Southern Finland (Tike, 2006)

In the present study it is assumed that wheat is grown to ripeness and only the kernels are used for biogas production; Møller (2007) determined the yield to be $0.43 \mathrm{Nm}^{3} * \mathrm{~kg} \mathrm{VS}^{-1}$ for wheat kernels.

\section{Нетр}

Latin: Cannabis spp.; English: hemp; Danish: hamp

Hemp is an annual crop that can be grown for non-drug purposes. The fibre can be used for a variety of purposes, but a license is required to cultivate hemp. The nutritional value of hemp is good, as it contains several unsaturated fatty acids in its oil-rich seeds. Selective breeding of hemp has mainly focused on producing strains that perform poorly in terms of drug production.

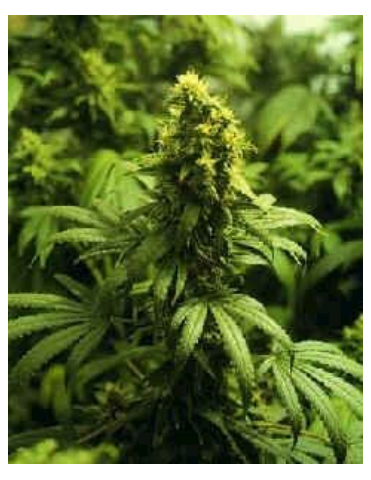
Fibre quality declines after flowering.

Table 15. Estimated dry matter yield and fertilizer consumption of hemp under different conditions in the studied countries

\begin{tabular}{|c|c|c|c|c|c|c|}
\hline \multirow[b]{2}{*}{ Yield in $\mathrm{kg} \mathrm{DM}$ * $\mathrm{ha}^{-1}$} & \multicolumn{2}{|c|}{ Denmark } & \multicolumn{2}{|c|}{ Sweden } & \multicolumn{2}{|c|}{ Finland } \\
\hline & $10000^{1}$ & $14000^{2}$ & $10000^{3}$ & $12000^{4}$ & $9000^{4}$ & $13000^{4}$ \\
\hline VS $\%$ of DM & & & & & & \\
\hline $\begin{array}{l}\text { N/P/K applied kg * } \\
\text { ha }^{-1}\end{array}$ & \multicolumn{2}{|c|}{$125 / 30 / 75$} & \multicolumn{2}{|c|}{$80 / 20 / 40$} & \multicolumn{2}{|c|}{ No data } \\
\hline Yield of $\mathrm{CH}_{4}$ & \multicolumn{6}{|c|}{$0.26 \mathrm{Nm}^{3} * \mathrm{~kg} \mathrm{VS}^{-1}$} \\
\hline
\end{tabular}

${ }^{1}$ Sandy soil in Denmark (Gylling, 2001), Landskontoret for Planteavl. 2000

${ }^{2}$ Loamy soil in Denmark (Gylling, 2001), Landskontoret for Planteavl. 2000

${ }^{3}$ Southern and mid Sweden (Christensson et al., 1997)

${ }^{4}$ Mid Finland (data not published)

Hemp has the potential to produce a very high dry matter yield. However, in the few studies in which the biogas potential has been determined, the methane yield has been disappointing. Escobar et al. (2007) obtained a methane yield of $0.26 \mathrm{Nm}^{3} * \mathrm{~kg} \mathrm{VS}^{-1}$ with a digestion time of 34 days 
(harvested in early September). A methane yield of $0.29 \mathrm{Nm}^{3} * \mathrm{~kg} \mathrm{VS}^{-1}$ (data not published) was achieved in Finland.

\section{Jerusalem artichoke}

Latin: Helianthus tuberosus; English: sun-root, choke, lambchoke.

The taste of Jerusalem artichoke is somewhere between that of artichoke and of radish. The tubers, which resemble potatoes, store the sugar inulin (70-80\%) instead of starch. The crop is therefore an im-

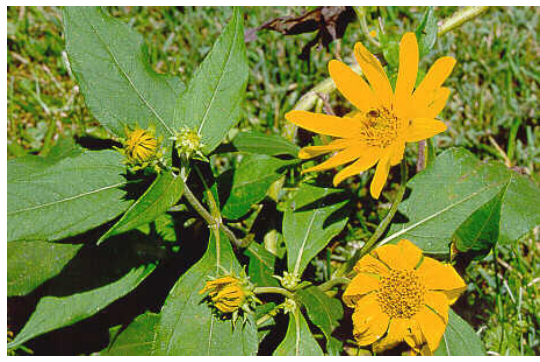
portant source of fructose for industry. It can also be used for producing alcohol.

Jerusalem artichoke is easy to cultivate. The roots can be harvested much the same way as are potatoes. Besides its roots, Helianthus tuberosus also has a very large above-ground biomass.

Table 16. Estimated dry matter yield and fertilizer consumption of Helianthus tuberosus under different conditions in the studied countries

\begin{tabular}{|c|c|c|c|c|c|c|}
\hline \multirow[b]{2}{*}{ Yield in $\mathrm{kg} \mathrm{DM}$ * ha $\mathrm{h}^{-1}$} & \multicolumn{2}{|c|}{ Denmark } & \multicolumn{2}{|c|}{ Sweden } & \multicolumn{2}{|c|}{ Finland } \\
\hline & $\begin{array}{l}8000^{1} \\
3000^{a}\end{array}$ & $\begin{array}{c}13000^{2} \\
3900^{a}\end{array}$ & $10000^{3}$ & $15000^{3}$ & $9000^{4}$ & $16000^{4}$ \\
\hline $\begin{array}{l}\text { VS \% of DM (Duke, } \\
1983)\end{array}$ & \multicolumn{2}{|c|}{95} & & & \multicolumn{2}{|c|}{95} \\
\hline $\begin{array}{l}\text { N/P/K applied kg * } \\
\mathrm{ha}^{-1}\end{array}$ & \multicolumn{2}{|c|}{$135 / 40 / 130$} & \multicolumn{2}{|c|}{$125 / 40 / 140$} & \multicolumn{2}{|c|}{ ? } \\
\hline Yield of $\mathrm{CH}_{4}$ & \multicolumn{6}{|c|}{$0.30 \mathrm{Nm}^{3} * \mathrm{~kg} \mathrm{VS}^{-1}$ (tops) $0.36 \mathrm{Nm}^{3} * \mathrm{~kg} \mathrm{VS}^{-1}$ (roots) } \\
\hline
\end{tabular}

${ }^{1}$ Low-yielding soil in Denmark (Henriksen and Bjørn, 2003); ${ }^{a}$ Top/root ratio yield is estimated to be $30 \%$ (Chabbert et al., 1983)

${ }^{2}$ High-yielding soil (Henriksen and Bjørn, 2003)

${ }^{3}$ Southern Sweden (Blomqvist, 2006)

${ }^{4}$ Yield of tops in southern Finland (Häggblom, 1988)

Helianthus tuberosus has a very high dry matter yield, especially when both the roots and tops are used. In Finland, the methane potential of the tops has been determined to be $0.30-0.43 \mathrm{Nm}^{3} * \mathrm{~kg} \mathrm{VS}^{-1}$ (Lehtomäki, 2006). The fermentability of the roots is very high and is estimated to be $0.36 \mathrm{Nm}^{3} * \mathrm{~kg} \mathrm{VS}^{-1}$ (Chabbert et al.,1983). In Sweden, the methane yield of fresh and ensiled tops was tested (Gunnarson et al., 1985) and found to be approximately $0.30 \mathrm{Nm}^{3} * \mathrm{~kg} \mathrm{VS}^{-1}$. Further investigation of this crop is needed. It remains to be determined whether it is best to use the tops, roots, or a combination of both for biogas production; it is thus of great interest to investigate the methane potential of the roots and tops at different harvest times. 



\section{Energy balances}

The system boundaries applied in the analyze include handling and transport of the crops and operation of biogas plants. The calculations included the production of inputs used in these processes, such as, chemical fertilizers, and vehicles and machinery used for transport and handling of raw materials. The crops included in the analyses are considered to be cultivated primarily for biogas production purposes. Hence, the energy needed and the environmental impact of cultivation and harvesting are included in the analyses. Chemical fertilizers were assumed to be used in the cultivation of crops. Digestate could be used to replace chemical fertilizers, however this study has been limited to not include the digestate use in the field. The modelling of each crop has been based on a total balance of one hectare of land

To calculate the energy balances of the studied crops, the following model is used:

$$
\begin{aligned}
& E B=35.9 \times B_{0} \times C y-\left(\sum_{n=1}^{N}\left(F_{n} \times P_{n} \operatorname{DiC}_{n}\right) \times 35.9 / 1000-\sum_{x=1}^{X}\left(\text { Fert }_{x} \times E F\right)-\right. \\
& \left.\sum_{z=1}^{Z}\left(\text { Pest }_{z} \times 2 \times 40 / 1000\right)-\sum_{y=1}^{y}\left(F^{\prime} P_{y} \times(L+M) / 1000\right)-C E B\right)
\end{aligned}
$$

where $E B$ is the energy balance in $\mathrm{GJ} / \mathrm{ha}, B o$ is the methane yield in terms of $\mathrm{Nm}^{3} / \mathrm{kg}$ VS (determined by batch digestion or feed analysis), $C y$ is the yield of the crop in terms of $\mathrm{kg} \mathrm{VS} / \mathrm{ha}, \mathrm{FOP}$ is the number of different field operations associated with cultivation, DiC is the diesel consumption of a specific field operation, Fert is the fertilizer consumption of N, $\mathrm{P}$, and $\mathrm{K}$ in $\mathrm{kg}, E F$ is the energy consumption associated with producing the fertilizer, Pest is the number of times pesticides are applied per year (assuming $2 \mathrm{~L}$ of formulated agent are used each time), $L$ is the lubricants used for machinery (3.6 MJ/L of diesel), $M$ is the energy used in constructing the machinery (12 MJ/L of diesel), and CEB is the energy consumption associated with anaerobic conversion in a biogas plant (calculated using the assumptions presented in Tables 17 and 18). 
Table 17. Inputs for calculating the process energy required for heat for 8500 tonnes of maize treated annually.

\begin{tabular}{ll}
\hline Parameter & Number \\
\hline Fermenter volume in $\mathrm{m}^{3}$ & $1031 \mathrm{~m}^{3}$ \\
Number of fermenters & 1 \\
Fermenter diameter in $\mathrm{m}$ & $12.00 \mathrm{~m}$ \\
Fermenter height in $\mathrm{m}$ & $9.12 \mathrm{~m}$ \\
K-value of the fermenter & $0.20 \mathrm{~W} / \mathrm{m}^{2} \mathrm{~K}$ \\
Specific heat of the substrate & $1.16 \mathrm{kWh} / \mathrm{m}^{3} \mathrm{C}$ \\
Process temperature & $35^{\circ} \mathrm{C}$ \\
\hline
\end{tabular}

Table 18. Inputs for calculating the process energy required for electricity for $\mathbf{8 5 0 0}$ tonnes of maize treated annually.

\begin{tabular}{|c|c|c|c|}
\hline & $\begin{array}{r}\text { Performance in } \\
(\mathrm{kW})\end{array}$ & $\begin{array}{r}\text { Daily operating } \\
\text { time }(h)\end{array}$ & $\begin{array}{r}\text { Energy demand } \\
(\mathrm{kWh} / \text { year })\end{array}$ \\
\hline Central pumping station & 20.00 & 10.00 & 73000 \\
\hline Mixer 1 & 20.00 & 10.00 & 73000 \\
\hline Mixer 2 & 20.00 & 10.00 & 73000 \\
\hline Others & 5.00 & 5.00 & 9125 \\
\hline Total $=5.4 \%$ of electric energy produced & & & 228125 \\
\hline
\end{tabular}

The energy inputs for a given crop are calculated from the values presented in Table 18 and 19 together with the number of operations and the amounts of energy required for them.

Table 19. Estimated energy consumption of various field operations, and consumption of pesticides and fertilizers.

\begin{tabular}{lll}
\hline Litres of diesel per treatment & & Reference \\
\hline Fertilizer/chemical application & 2 & Dalgaard et al., 2001 \\
Seedbed harrowing & 4 & Dalgaard et al., 2001 \\
Combined harrow and sowing & 3 & Dalgaard et al., 2001 \\
Sowing of grass & 0.5 & Dalgaard et al., 2001 \\
Rolling & 2 & Dalgaard et al., 2001 \\
Pesticide spraying & 1.5 & Dalgaard et al., 2001 \\
Combine harvesting & 14 & Dalgaard et al., 2001 \\
Transport of cereals & 5 & FAO, 1989 \\
Straw baling & 2 & FAO, 1989 \\
Transport of straw & 4 & FAO, 1989 \\
Stubble cultivation & 7 & FAO, 1989 \\
Ploughing & 20 & Dalgaard et al., 2001 \\
Grass cutting & 5 & FAO, 1989 \\
Grass spreading & 1 & FAO, 1989 \\
Tedding & 2 & FAO, 1989 \\
Cutting, unloading, and transport of grass & 12 & Dalgaard et al., 2001 \\
Cutting, unloading, and transport of maize and & 50 & Estimated \\
beets (excl. tops) & & \\
Harvesting miscanthus & 61 & Fløjgård, 2001 \\
Pesticides & MJ/kg & \\
$N$ & 40 & Dalgaard et al., 2001 \\
P & 50 & Dalgaard et al., 2001 \\
K & 12 & Dalgaard et al., 2001 \\
& 7 & Dalgaard et al., 2001 \\
\hline
\end{tabular}




\subsection{Energy input and output}

Figure 4 presents the energy inputs for crop cultivation and conversion in a biogas plant for the studied crops in the studied countries. The largest energy input is in most cases the indirect use of energy in producing ferti

Denmark

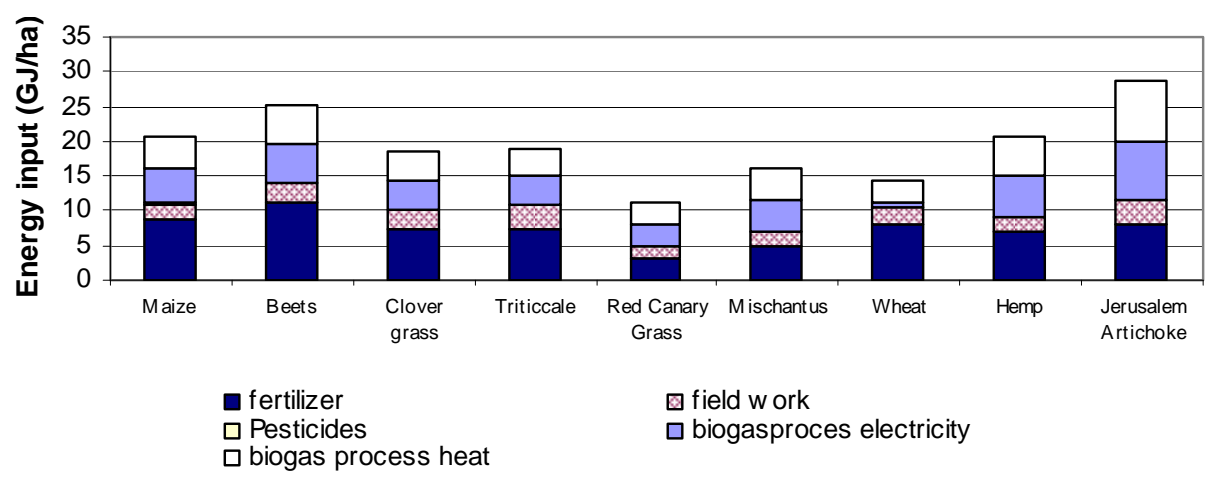

Sweden

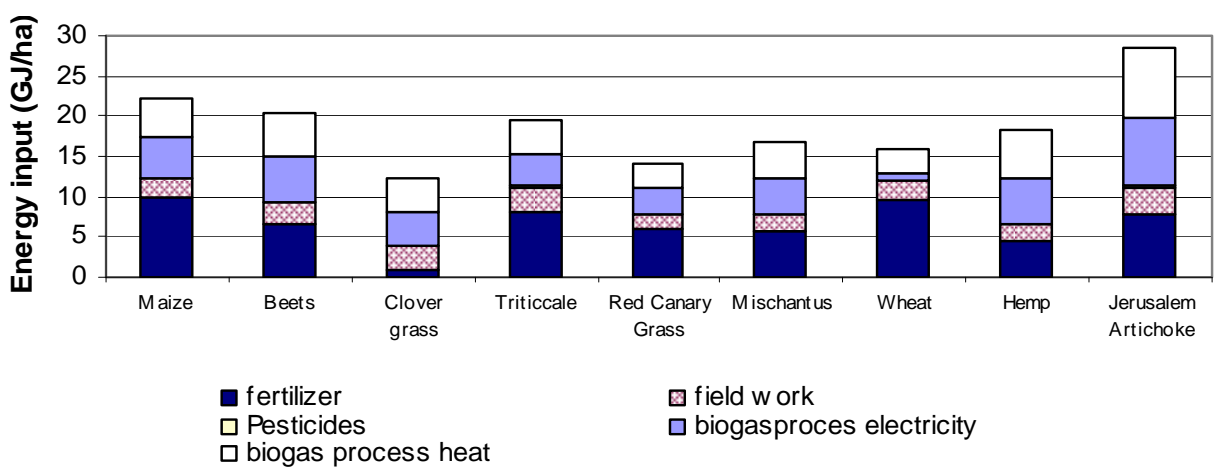

Finland

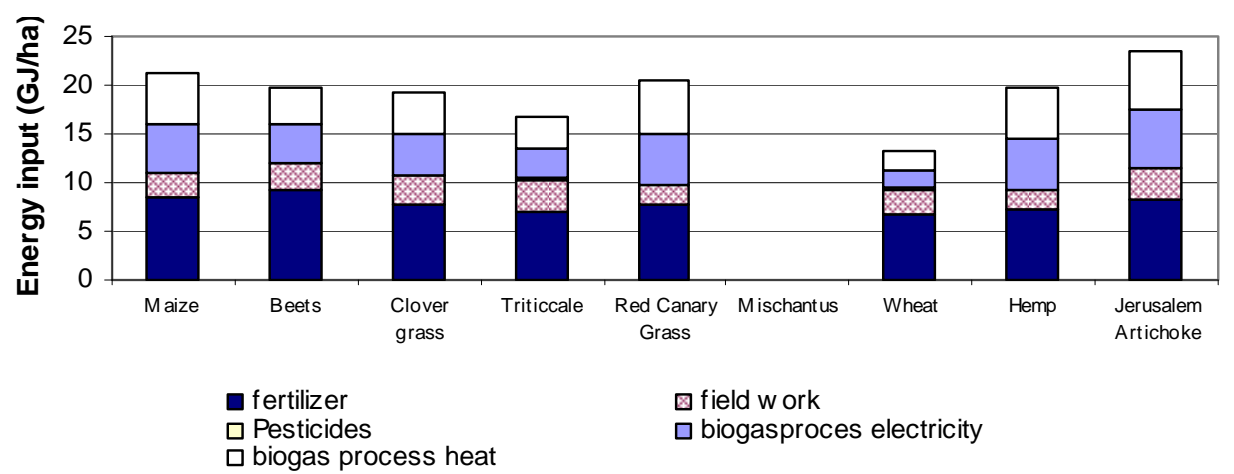

Figure 4. Energy input for cultivating various crops and converting them in a biogas plant in different countries. 
lizer (especially nitrogen), followed by the heat and electricity used for the conversion of biomass in a biogas plant. In the case of some crops there is a significant difference between countries; for example, clover requires a lower energy input in Sweden than in the other countries, because for Sweden the calculations were based on cultivation with little added nitrogen.

\section{Denmark}

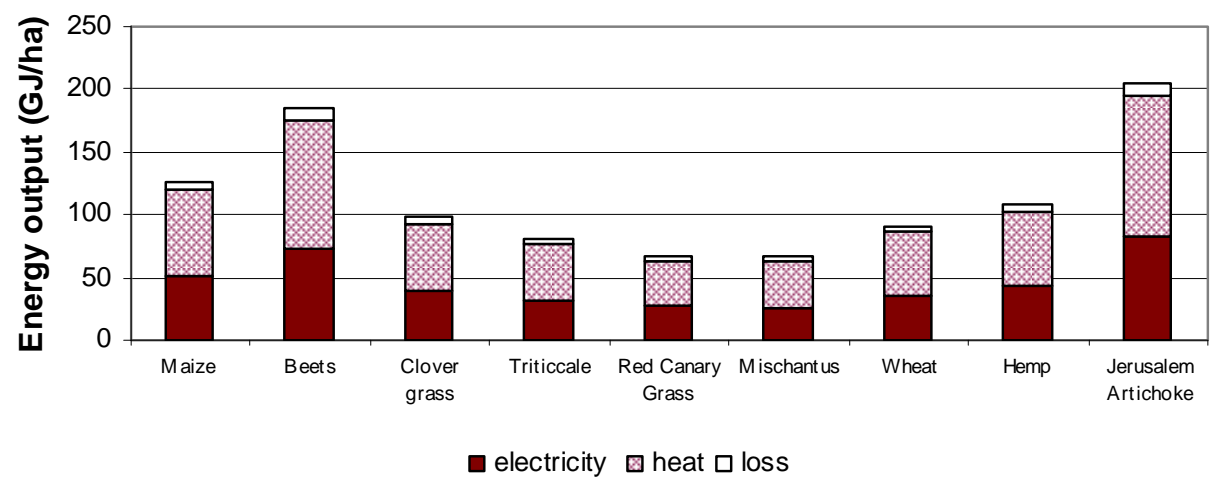

Sweden

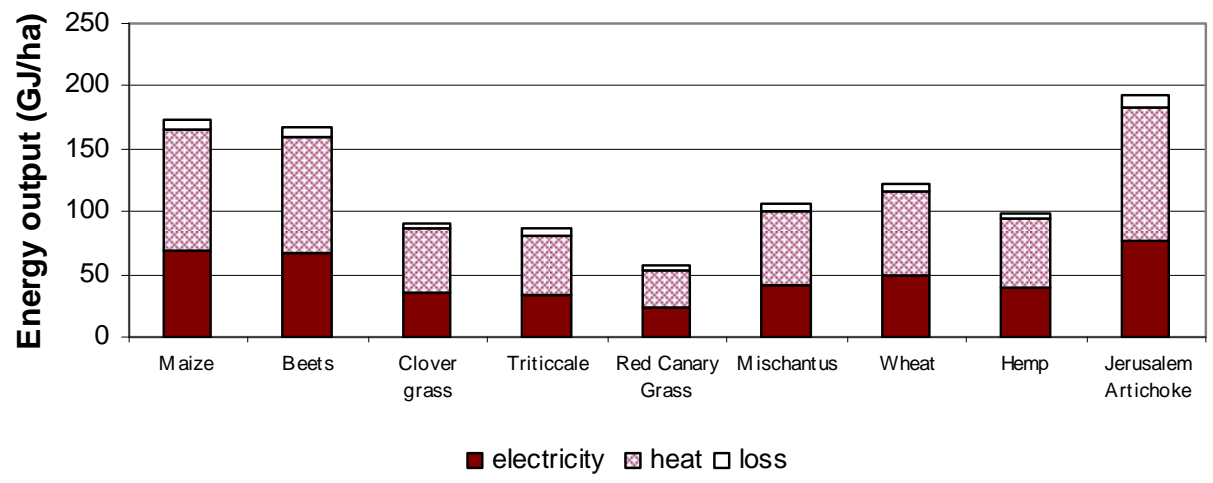

Finland

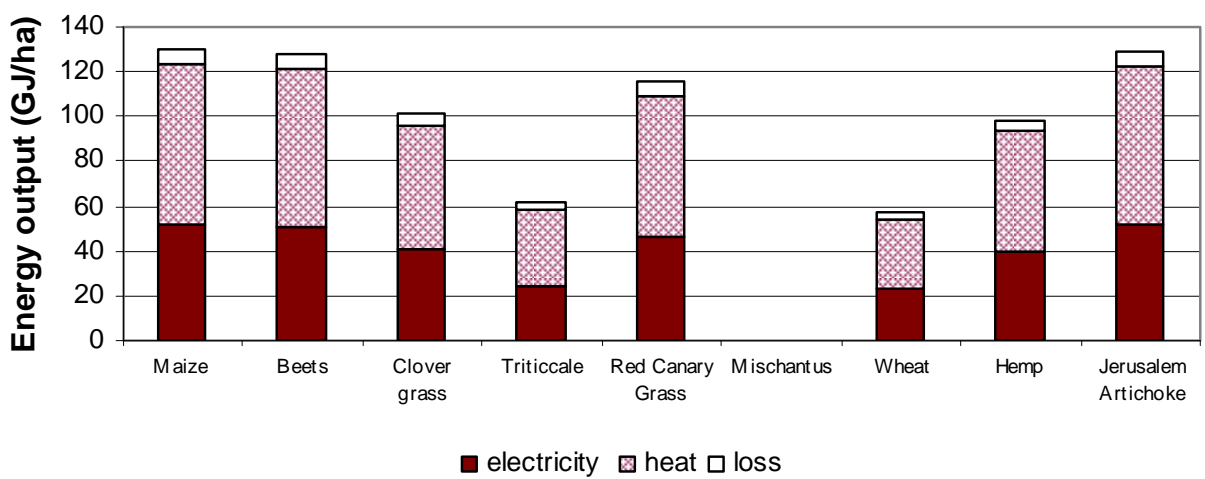

Figure 5. Energy output of the anaerobic digestion of various crops in biogas plants in different countries. 
Figure 5 presents the average energy output in the forms of heat and electricity of the different crops in the three studied Nordic countries. In all the countries, Jerusalem artichoke, maize, and beets produce the highest energy yield per hectare of land.

By subtracting the energy input from the energy output, the net energy yields of the studied crops can be calculated; the net energy yields of the different crops are presented in Figure 6.

The most promising crops in terms of producing the most net energy are in all studied countries Jerusalem artichoke, maize, and beets. In Finland, however, reed canary grass is also a promising candidate.

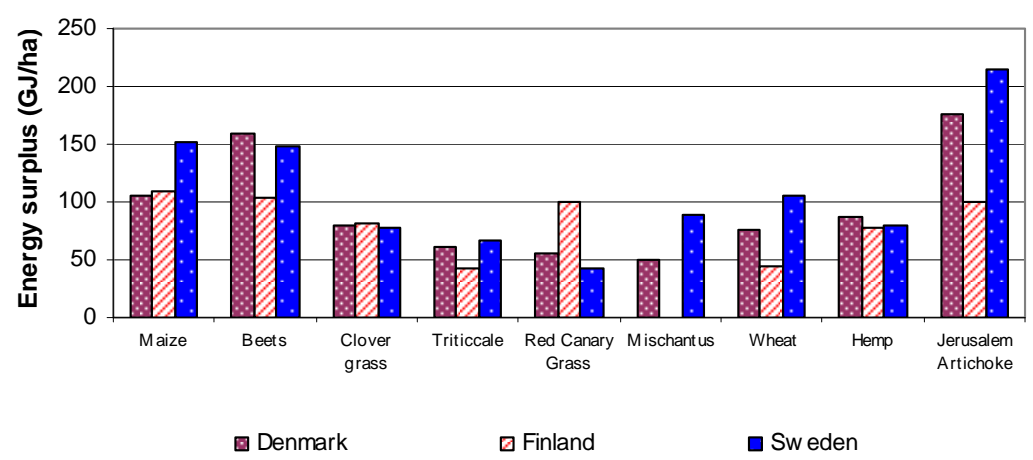

Figure 6. Net energy output of the anaerobic digestion of various crops.

Besides the net energy production per hectare, the energy ratio is also of interest. The energy ratio is calculated as the total energy output divided by the total energy input required for cultivation and conversion, and can be defined as the net amount of energy one obtains when putting one unit of energy into the system. The energy ratio differs between crops and countries, generally being lower in Finland than in the other countries due to less solar radiation and a shorter growing season.

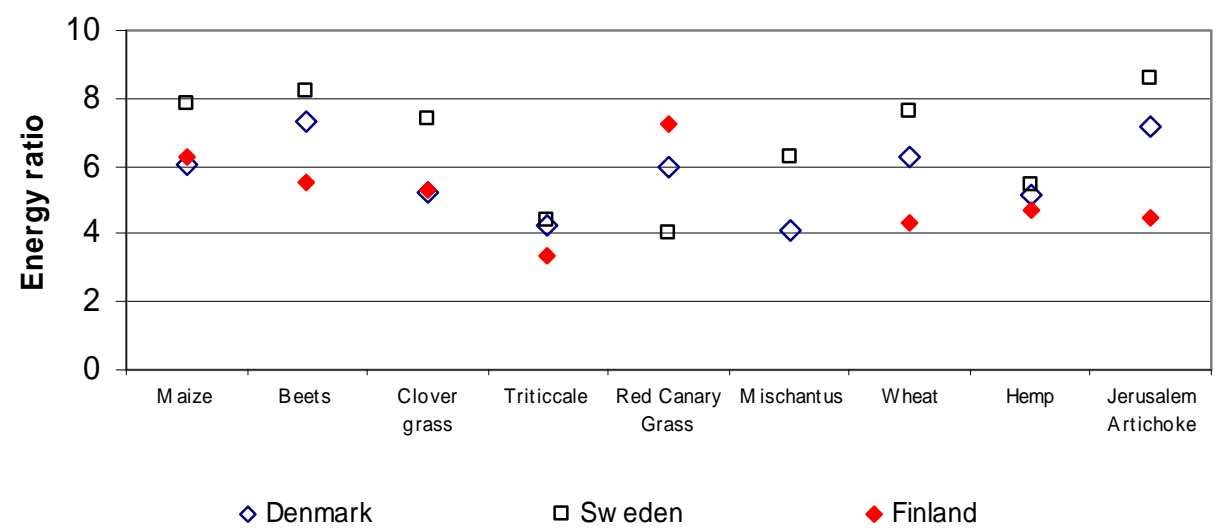

Figure 7. The energy ratios of various crops, calculated as the total energy output divided by the total energy input required for cultivation and conversion. 
In this study all energy input in the form of fertilizer, pesticides, diesel, lubricants for machinery were included as was the process energy used for the processing on the biogas plant. It was decided that the model used for this study is based on a biogas system where the energy crop is used as the only feedstock with a hydraulic retention time of 40 days. However the results of the energy balances of the crops can without problems be used in systems were the crops are used as a co-substrate. The methodology is the same as has been used in other studies. However the different studies differ in the assumptions made about system design and the systems boundaries chosen. The present study has not included energy savings by substituting chemical fertilizer with the fertilizers in the digestate from the biogas plants, thus slightly underestimating the energy output compared to some other studies. On the other hand the transport, storage and spreading of digestate have not been included and it is assumed that these factors in many cases neutralize each other.

\subsection{Fermented residues}

This study has not included the biodigestate use in the field in the energy balances. However when energy crops are used as a feedstock it is possible to use biodigestate as a fertiliser, which would reduce the need for commercial fertiliser; this would be especially valuable for organic farmers. There are several advantages of using digestate as a fertilizer in agriculture. All the plant nutrients in the raw materials digested are preserved in the digestate. Anaerobic digestion can therefore allow for recirculation of plant nutrients and in the case of growing nitrogen fixation crops even supply new sources of nitrogen. The digestate contains a high proportion of plant-available nitrogen. This is due to the mineralization that takes place during the degradation process, in which organic-bound nitrogen is converted into ammonium. Cultivation of energy crops can be employed at organic farms without animals to provide plant nutrients to the cropping system (Berglund, 2006) and in this case especially clover grass is of interest. In traditional organic farming the clover grass is cut frequently during the cropping season and the plant material is left on the fields. However, much of the nitrogen in the cut plant material may not be available in the following year due to leaching processes and the fixed nitrogen can not be transferred to other fields with nitrogen demanding crops.

Anaerobic digestion can also be employed to increase the content of organic matter in arable soil, for example, by the spreading of digestate rich in organic matter. Increased soil organic matter can improve the soil structure, and the capacity of the soil to retain water. Improved soil structure reduces the vulnerability to compaction of the soil, and facilitates root penetration, drainage and aeration (Berglund, 2006). 


\section{Greenhouse gas balances}

Anthropogenic emissions of the greenhouse gases $\mathrm{CO}_{2}, \mathrm{CH}_{4}$, and nitrous oxide $\left(\mathrm{N}_{2} \mathrm{O}\right)$ have increased significantly over the last century. Measures to reduce global warming due to the greenhouse effect tend to focus on reducing $\mathrm{CO}_{2}$ emissions produced by burning fossil fuels. The amounts of $\mathrm{CH}_{4}$ and $\mathrm{N}_{2} \mathrm{O}$ emitted to the atmosphere are lower than that of $\mathrm{CO}_{2}$, but their global warming potentials are 21 and 310 times higher, respectively. Anaerobically digesting manure and crops produces biogas that can replace fossil fuels, thereby reducing $\mathrm{CO}_{2}$ emissions. However, cultivating crops for biogas production entails diesel combustion, which emits $\mathrm{CO}_{2}$, and using fertilizers, which require energy for their production. Furthermore, crop cultivation results in $\mathrm{N}_{2} \mathrm{O}$ emissions from the fields.

\section{Nitrous oxide}

Direct $\mathrm{N}_{2} \mathrm{O}$ emissions from agricultural soils are estimated by:

$$
\mathrm{N}_{2} \mathrm{O}_{\text {Direct }}-\mathrm{N}=\left[\left(\mathrm{F}_{\mathrm{SN}} * \mathrm{EF}_{1}\right]\right.
$$

where,

$\mathrm{N}_{2} \mathrm{O}_{\text {Direct }}-\mathrm{N}=\mathrm{N}_{2} \mathrm{O}$ emissions in units of nitrogen

$\mathrm{F}_{\mathrm{SN}}=$ amount of synthetic nitrogen fertilizer applied annually to soils, adjusted to account for the amount that volatilizes as $\mathrm{NH}_{3}$ and $\mathrm{NO}_{\mathrm{x}}$

$\mathrm{EF}_{1}=$ emissions factor for emissions arising from $\mathrm{N}$ inputs ( $\mathrm{kg}$ $\mathrm{N}_{2} \mathrm{O}-\mathrm{N} / \mathrm{kg} \mathrm{N}$ input).

The use of manure, the effect of crop residues, and fixation of nitrogen are not included in the calculation. A default value of $1.25 \%$ is used for $\mathrm{EF}_{1}$ (IPCC, 1996) and a fixed loss rate of $10 \%$ is used for the amount of nitrogen lost due to evaporation from synthetic fertilizer. Tables 20, 21, and 22 present calculations of the total greenhouse gas balances; the following assumptions were used in making these calculations:

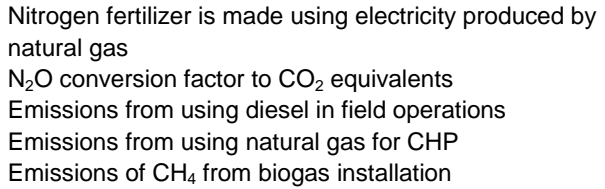

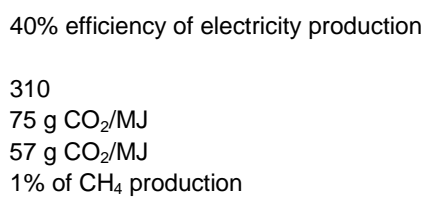


The effect of biofuel cropping on the soil organic matter content is not included in the calculations; the effect could be positive, especially in the case of perennial crops, though in the case of annual crops the effect could be negligible or even negative.

Table 20. The greenhouse gas balances of the various crops grown in Denmark.

\begin{tabular}{|c|c|c|c|c|c|c|c|c|c|}
\hline Effect & $\begin{array}{l}\stackrel{\stackrel{N}{N}}{\stackrel{N}{\pi}} \\
\text { Whole } \\
\text { crop }\end{array}$ & 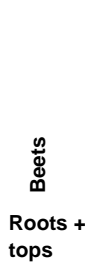 & 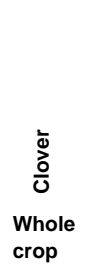 & 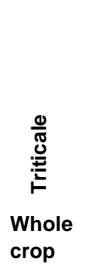 & 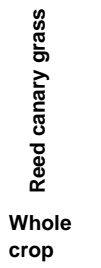 & 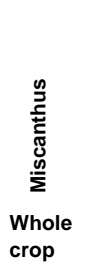 & $\begin{array}{c}\stackrel{+\pi}{\Xi} \\
\stackrel{\Xi}{3} \\
\text { Grain }\end{array}$ & $\begin{array}{l}\frac{\varrho}{\bar{\Xi}} \\
\stackrel{ \pm}{I} \\
\text { Whole } \\
\text { crop }\end{array}$ & 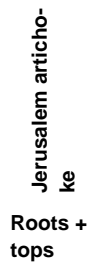 \\
\hline $\begin{array}{l}\text { Emissions, field, } \\
\mathrm{kg} \mathrm{N}_{2} \mathrm{O} / \mathrm{ha}\end{array}$ & 2.6 & 3.0 & 1.8 & 2.4 & 0.9 & 1.6 & 2.5 & 2.2 & 2.4 \\
\hline $\begin{array}{l}\text { Emissions, field, } \\
\mathrm{kg} \mathrm{CO}_{2} \text { equivalents/ha }\end{array}$ & -800 & -943 & -548 & -740 & -274 & -493 & -767 & -685 & -740 \\
\hline $\begin{array}{l}\text { Emissions, biogas } \\
\text { plant, } \mathrm{kg} \mathrm{CO} / \mathrm{ha}\end{array}$ & -735 & -1078 & -570 & -474 & -394 & -387 & -528 & -629 & -1199 \\
\hline $\begin{array}{l}\text { Substitution of } \\
\text { natural gas, } \mathrm{kg} \mathrm{CO}_{2} / \mathrm{ha}\end{array}$ & 7164 & 10500 & 5557 & 4617 & 3835 & 3770 & 5146 & 6129 & 11680 \\
\hline Fertilizer, $\mathrm{kg} \mathrm{CO} / \mathrm{ha}$ & -1223 & -1605 & -1045 & -1071 & -437 & -696 & -1139 & -1017 & -1160 \\
\hline Field work, $\mathrm{kg} \mathrm{CO}_{2} / \mathrm{ha}$ & -172 & -205 & -221 & -241 & -140 & -170 & -178 & -159 & -245 \\
\hline $\begin{array}{l}\text { Biogas process (heat } \\
\text { and electricity), } \mathrm{kg} \mathrm{CO}_{2} / \mathrm{ha}\end{array}$ & -556 & -631 & -474 & -467 & -357 & -516 & -217 & -659 & -980 \\
\hline Total effect, $\mathrm{kg} \mathrm{CO}_{2} / \mathrm{ha}$ & 3678 & 6039 & 2698 & 1625 & 2233 & 1508 & 2317 & 2981 & 7356 \\
\hline
\end{tabular}

Table 21. The greenhouse gas balances of the various crops grown in Finland; for Jerusalem artichoke, only the yield of tops is included in the calculations.

\begin{tabular}{|c|c|c|c|c|c|c|c|c|c|}
\hline Effect & $\begin{array}{l}\stackrel{0}{N} \\
\stackrel{\text { N0 }}{\Sigma}\end{array}$ & $\begin{array}{l}\mathscr{0} \\
\Phi\end{array}$ & 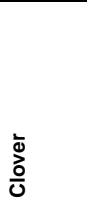 & 荧 & 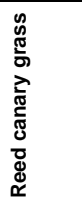 & 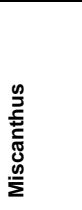 & 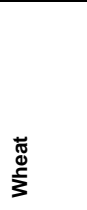 & $\begin{array}{l}\stackrel{0}{\bar{\Xi}} \\
\text { İ }\end{array}$ & 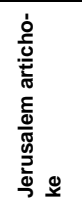 \\
\hline & $\begin{array}{r}\text { Whole } \\
\text { crop }\end{array}$ & $\begin{array}{r}\text { Roots }+ \\
\text { tops }\end{array}$ & $\begin{array}{r}\text { Whole } \\
\text { crop }\end{array}$ & $\begin{array}{r}\text { Whole } \\
\text { crop }\end{array}$ & $\begin{array}{r}\text { Whole } \\
\text { crop }\end{array}$ & $\begin{array}{r}\text { Whole } \\
\text { crop }\end{array}$ & Grain & $\begin{array}{r}\text { Whole } \\
\text { crop }\end{array}$ & $\begin{array}{r}\text { Roots+ } \\
\text { tops }\end{array}$ \\
\hline $\begin{array}{l}\text { Emissions, field, } \\
\mathrm{kg} \mathrm{N}_{2} \mathrm{O} / \mathrm{ha} \\
\text { Emissions, field, }\end{array}$ & 2,6 & 2,5 & 2,3 & 2,3 & 2,3 & 0,0 & 1,9 & 2,2 & 2,4 \\
\hline $\begin{array}{l}\mathrm{kg} \mathrm{CO} 2 \text { equivalents/ha } \\
\text { Emissions, biogas }\end{array}$ & -800 & -767 & -712 & -712 & -712 & 0 & -603 & -685 & -740 \\
\hline $\begin{array}{l}\text { plant, } \mathrm{kg} \mathrm{CO} / \mathrm{ha} \\
\text { Substitution of }\end{array}$ & -763 & -745 & -591 & -362 & -675 & 0 & -334 & -577 & -756 \\
\hline natural gas, $\mathrm{kg} \mathrm{CO} / \mathrm{ha}$ & 7433 & 7259 & 5763 & 3531 & 6578 & 0 & 3257 & 5618 & 7367 \\
\hline Fertilizer, $\mathrm{kg} \mathrm{CO}_{2} / \mathrm{ha}$ & -1223 & -1314 & -1107 & -1010 & -1107 & 0 & -976 & -1017 & -1160 \\
\hline Field work, $\mathrm{kg} \mathrm{CO}_{2} / \mathrm{ha}$ & -172 & -205 & -221 & -241 & -140 & 0 & -178 & -159 & -245 \\
\hline $\begin{array}{l}\text { Biogas process (heat } \\
\text { and electricity), } \mathrm{kg} \mathrm{CO}_{2} / \mathrm{ha}\end{array}$ & -577 & -437 & -491 & -357 & -612 & 0 & -137 & -604 & -686 \\
\hline Total effect, $\mathrm{kg} \mathrm{CO}_{2} / \mathrm{ha}$ & 3899 & 3792 & 2639 & 848 & 3331 & 0 & 1029 & 2577 & 3780 \\
\hline
\end{tabular}


Table 22. The greenhouse gas balances of the various crops grown in Sweden.

\begin{tabular}{|c|c|c|c|c|c|c|c|c|c|}
\hline Effect & 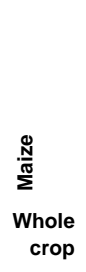 & $\begin{array}{r}\stackrel{\mathscr{\Xi}}{\Xi} \\
\Phi \\
\text { Roots + } \\
\text { tops }\end{array}$ & $\begin{array}{l}\text { さे } \\
\text { Ù } \\
\text { Whole } \\
\text { crop }\end{array}$ & 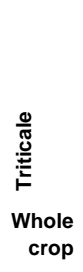 & 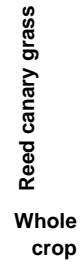 & 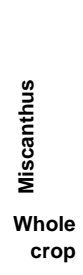 & 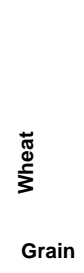 & 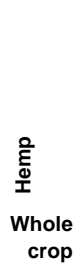 & 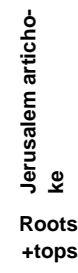 \\
\hline $\begin{array}{l}\text { Emissions, field, } \\
\mathrm{kg} \mathrm{N} \mathrm{N}_{2} \mathrm{O} / \mathrm{ha} \\
\text { Emissions, field, }\end{array}$ & 3,2 & 2,1 & 0,0 & 2,7 & 1,8 & 1,8 & 3,2 & 1,4 & 2,2 \\
\hline $\begin{array}{l}\mathrm{kg} \mathrm{CO}_{2} \text { equivalents/ha } \\
\text { Emissions, biogas } \\
\text { plant, } \mathrm{kg} \mathrm{CO}_{2} / \mathrm{ha}\end{array}$ & -986 & -658 & -529 & -822 & -548 & -548 & -986 & -438 & -1427 \\
\hline $\begin{array}{l}\text { Substitution of } \\
\text { natural gas, } \mathrm{kg} \mathrm{CO}_{2} / \mathrm{ha}\end{array}$ & 9911 & 9587 & 5151 & 4889 & 3245 & 6016 & 6915 & 5618 & 13905 \\
\hline Fertilizer, $\mathrm{kg} \mathrm{CO}_{2} / \mathrm{ha}$ & -1423 & -927 & -134 & -1141 & -855 & -797 & -1367 & -644 & -1099 \\
\hline Field work, $\mathrm{kg} \mathrm{CO}_{2} / \mathrm{ha}$ & -172 & -205 & -221 & -241 & -140 & -170 & -178 & -159 & -256 \\
\hline $\begin{array}{l}\text { Biogas process (heat } \\
\text { and electricity), } \mathrm{kg} \mathrm{CO} / \mathrm{ha}\end{array}$ & -769 & -577 & -439 & -494 & -302 & -824 & -271 & -604 & -1167 \\
\hline Total effect, $\mathrm{kg} \mathrm{CO}_{2} / \mathrm{ha}$ & 5543 & 6237 & 3828 & 1689 & 1067 & 3061 & 3404 & 3196 & 9271 \\
\hline
\end{tabular}

From the tables it can be seen that the different studied crops have different effects on the total greenhouse gas balance. In Denmark and Sweden, Jerusalem artichoke has the greatest impact in terms of reducing greenhouse gas emissions, followed by beets and then maize; in Finland, however, Jerusalem artichoke does not have as great an impact, mainly because only the tops are included in the calculations.

When the impacts on greenhouse gas emissions of using crops for biogas production are calculated, the assumptions used in the calculations are very important. One particularly important assumption concerns the amount of methane leaking from the biogas plants, including that produced while storing the degassed effluent. In the present calculations a methane loss of $1 \%$ of the total produced gas is assumed. However, this amount could be considerably higher in many cases. For many crops, a methane loss of less than $8 \%$ could mean that, instead of having a positive impact, biogas production could have a negative impact on the greenhouse gas balance (Figure 8). Thus, it is extremely important to reduce the methane loss to an absolute minimum, to achieve a high, positive impact on the greenhouse gas balance. However in the case of using manure for biogas production the impact on the greenhouse gas balance will almost always be positive since high emissions of $\mathrm{CH}_{4}$ produced during storage of non treated manure is avoided. 


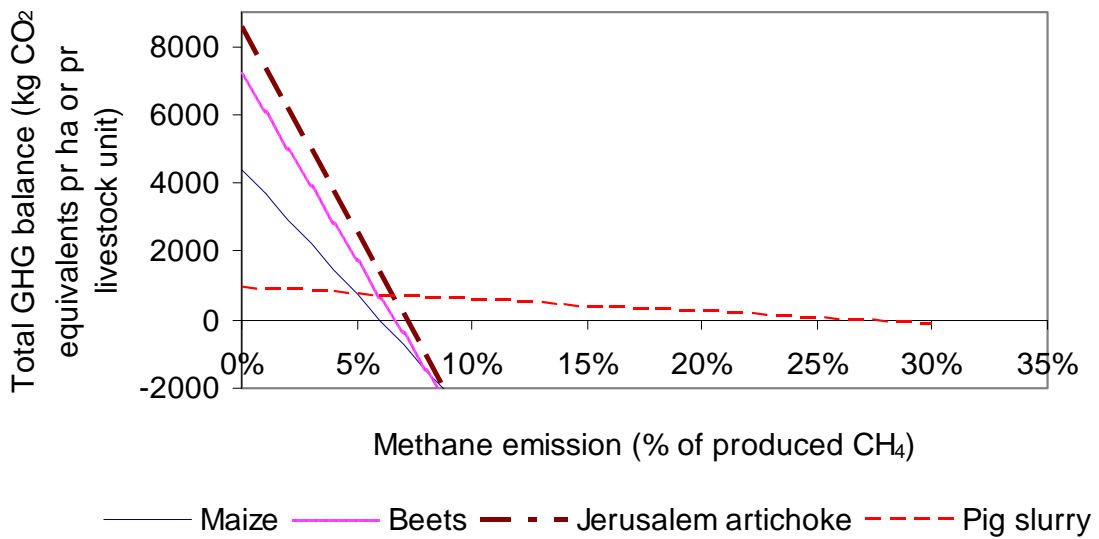

Figure 8. The total GHG balance in $\mathrm{CO} 2$ equivalents in terms of methane emission during processing for Danish conditions. 


\section{Conclusion}

The present study has evaluated the development of biogas technology in three Nordic countries and analysed the effect of using energy crop feedstocks in biogas plants, either alone or to supplement manure.

The biogas production situation and the incentives and barriers to producing biogas differ between the three countries and nine "model" crops were evaluated. Biogas production from crops can result in a high net energy output of more than $150 \mathrm{GJ} / \mathrm{ha}$ and a reduction of $9000 \mathrm{~kg}$ of $\mathrm{CO}_{2}$ equivalents/ha/year, making it superior to technologies such as bioethanol and biodiesel production. When promoting the expansion of biogas production from crops, the net energy output per hectare and effect on greenhouse gas emissions should be taken into account.

The energy balances and impact on greenhouse gases of the studied crops differs between the countries. In Sweden and Denmark, the same crops turned out to be the most promising in terms of energy yield and impact on greenhouse gases. In Denmark and Sweden, Jerusalem artichoke has the best energy yield. In Finland, however, where only the tops of this crop are assumed to be used, the advantages of Jerusalem artichoke do not stand out as much, though it is still superior to most biofuel crops and at the same level as the best crops. Notably, reed canary grass has produced some promising results in Finland. It should be emphasized that using the roots of Jerusalem artichoke for biogas production presents many challenges in terms of harvesting, cleaning, etc. Maize and beets yield a very high energy output in all countries.

Based on the examined parameters, it can be concluded that the most promising crops are Jerusalem artichoke, beets, maize, and, in Finland, reed canary grass as well. However, goals other than simply energy production and reduced greenhouse gas emissions might be equally important. Important goals not covered in the study are low pesticide consumption, low nitrate leaching, securing clean groundwater, ability to fix nitrogen, and the ability to build soil organic matter. These goals are best achieved with perennial crops such as clover, miscanthus, and reed canary grass.

Using biogas to achieve the EU goal for the proportion of transport fuel derived from biofuels is an environmentally effective choice, since its energy balance turns out to be better than those of the ethanol and biodiesel alternatives. However, there are different barriers and incentives in Sweden, Denmark, and Finland to introducing biogas in the transport sector.

Sweden has promoted the use of biogas for transport; thus, there are 60-70 public biogas fuelling stations, biogas used as a vehicle fuel is 
exempt from tax, and there is free parking in some cities for cars running on biogas; the same incentives do not apply in the other countries. Only by making biogas used in the transport sector tax exempt will this technology be competitive with fossil fuels.

When the impacts on greenhouse gas emissions of using crops for biogas production are evaluated one particularly important assumption concerns the amount of methane leaking from the biogas plants. In the present study a methane loss of $1 \%$ of the total produced gas is assumed. However, this amount could be considerably higher in many cases. For many crops, a methane loss of less than $8 \%$ could mean that, instead of having a positive impact, biogas production could have a negative impact on the greenhouse gas balance. Thus, it is extremely important to reduce the methane loss to an absolute minimum, to achieve a high, positive impact on the greenhouse gas balance when using energy crops. However in the case of using manure for biogas production the impact on the greenhouse gas balance will almost always be positive since high emissions of $\mathrm{CH}_{4}$ produced during storage of non treated manure is avoided. 


\section{References}

Amon, T., Amon, B., Kryvoruchko, V., Zollitsch, W., Mayer, K., and Gruber, L. 2007. Biogas production from maize and dairy cattle manure - Influence of biomass composition on the methane yield. Agriculture Ecosystems \& Environment 118 (1-): 173-182 Jan 2007.

Berglund, M. 2006 Biogas production from a systems analytical perspective. PhD dessertation. Faculty of engineering, Lund University.

Björnsson 2002. Agrigas - Utveckling av teknik för att utnyttja biogaspotentialen i restprodukter med höga torrhalter. Resultat- och ekonomirapport 2000-2002. Avdelningen för bioteknik. Lunds Universitet.

Börjesson, 2004. Energianalys av drivmedel från spannmål och vall. Rapport nr 54.

Chabbert, N., Ph. Braun, J. P. Guiraud, M. Arnoux and P. Galzy. 1983. Productivity and fermentability of Jerusalem artichoke according to harvesting date. Biomass, Volume 3, Issue 3, 1983, Pages 209-224.

Erik Fløjgaard Kristensen. 2003 In: Jørgensen, U. \& Verwijst, T. (eds.), Harvesting and handling of miscanthus - Danish experiences. /, DIAS report - Plant Production 86. 2003. s. 41-46

Christensson K. et al 1997. Databank Industrigödor. Hushållningssällskapet Malmöhus.

Commission on oil independence, 2006. På väg mot ett oljefritt Sverige, Kommissionen mot oljeberoende, June.

Duke J.A. 1983. Helianthus tuberosus L.. Handbook of energy crops. Unpublished.

Dalgaard T, Halberg N, Porter JR 2001.A model for fossil energy use in Danish agriculture used to compare organic and conventional farming AGRICULTURE ECOSYSTEMS \& ENVIRONMENT 87 (1): 51-65 OCT 2001

Danish Institute of Agricultural and Fisheries Economics. 1999. Centralised Biogas Plants -Integrated Energy Produc- tion, Waste Treatment and Nutrient Redistribution Facilities. Ed. Johannes Christensen.

Escobar F., Kreuger E. And Björnsson L. 2007. Project work batch digestion of hemp. Not published.

FAO. 1989. Energy consumption and input-output relations of field operations. Edited by Evzen Pick, Olle Noren and Villy Nielsen. Food and agriculture organisation of the United Nations

Fordonsgas 2006.

http://www.fordonsgas.se (accessed 18 June 2006).

Graversen J. and Gylling M. 2002. Energiafgrøder til fastbrændsels formål - produktionsøkonomi, håndteringsomkostninger og leveringsplaner. Working paper. Fødevareøkonomisk Institut.

Gunnarson S, Malmberg A, Mathisen B, 1985. Jerusalem Artichoke (Helianthus-Tuberosus $L$ ) for biogas production BIOMASS 7 (2): 85-97

Gylling M. 2001. Energiafgrødeprogrammet. Hovedrappport nr. 31. Statens jordbrugs- og fiskeriøkonomiske Institut.

Held, 2006. Förnybar gas - samverkan mellan naturgas och förnybar gas. Rapport från Gasföreningen.

Henriksen, K. and Bjørn, G. 2003. Jordskok - en gammel dansk grønsag. Grøn Viden Havebrug.

Herland E. 2005. LRFs energiscenario till år 2020 (The federations of Swedish farmers energy scenario for the year 2020). Report from the Federation of Swedish Farmers.

IPCC, 1997. Greenhouse Gas Inventories. Revised 1996 IPCC Guidelines for National Greenhouse Gas

Jarvis, 2006. Biogas i Sverige, 1996-2006. 10-årsjubileum för biogas till fordon.

Jarvis Å. and Svensson K. 2007. Produktion och användning av biogas år 2005 (Production and use of biogas the year 2005). Report by the Swedish Energy Agency.

Jönsson, 2005. Biogas as vehicle fuel presentation, 2005-03-16. 
http://www.sgc.se/nyheter/display.asp?I D=547 (Date: 2006-06-05)

Khan, J., 2003. Planning of biogas plants. A question of co-operation and negotiation. Report nr 37. Environmental and Energy Systems Studies, Lund University (in Swedish with English summary).

Kangas, A., Laine, A., Niskanen, M., Salo, Y., Vuorinen, M., Jauhiainen, L. \&Nikander, H. 2006. Results of official variety trials 1999-2006. 224 p., Publications No. 132., MTT Agrifood Research, Jokioinen

Landscenteret. 2006.Budgetkalkuler for de enkelte produktionsgrene.

Landskontoret for Planteavl. 2000. Dyrkning af hamp i Danmark. Nr. 05.194 • Arkiv 31.51

Lantz M., Svensson M., Björnsson L. and Börjesson, P. 2007. The prospects for an expansion of biogas systems in Sweden - Incentives, barriers and potentials. Energy Policy 35 (3), 1830-1843.

Lehtomaki A. 2006. Biogas production from Energy crops and crop residues. PhD dissertation.

Lehtomäki, A., and Björnsson, L. 2006 Two-stage anaerobic digestion of energy crops: Methane production, nitrogen mineralisation and heavy metal mobilisation. Environ. Technol. 27: 209-218.

Linné M., Jönsson O. and Rietz J. 2005. Litteraturstudie - Sammanställning och analys av potentialen för produktion av förnyelsebar metan (biogas och SNG) i Sverige (An literature study - Gathering and analyse of the potential production of renewable methane (biogas and SNG) in Sweden). Report, Biomil Ltd. and the Swedish Gas Centre.

Madsen, K.H.M. Activities on Bioenergi. Seminar on bioenergy, 23/8 2006. Danish advisory center.

Møller H.B., Nielsen L. and Christensen T. 2007. Biogas production from different types of biomass and grass species from meadows. NJF congress, Copenhagen 2007.

Møller H.B. 2007. Anvendelse af halm i biogasanlæg og muligheden for at øge energiudnyttelsen. Intern rapport. DJF markbrug 2007, nr. 8. Aarhus Universitet.

Møller H.B. 2007. Results from batch digestion. Not published.

Månsson L. 2006. Certifieringsre- gler för biogödsel (Certification rules for biofertilisers). Report from SP Swedish National Testing and Research Institute.

Nordberg Å., Lindberg A., Gruvberger C., Lilja T. and Edström M. 1998. Biogaspotential och framtida anläggningar i Sverige (Biogas potential and future biogas plants in Sweden). Report nr 17 (Recycle and Waste). Swedish Institute of Agricultural Engineering in co-operation with VBB Viak, a SWECO company.

Persson M. 2007 Biogas - a renewable fuel for the transport sector for the present and the future. Article from the Swedish Gas Centre.

Olesen, J. E. (red.), 2005. Drivhusgasser fra jordbruget - reduktionsmuligheder. DJF rapport Markbrug nr. 113, 159 pp.

Raven R.P.J.M. and Gregersen K.H.. 2005 Renewable and Sustainable Energy Reviews xx (2005) 1-18.

RVF, 2005. Användning av biogödsel (The use of biomanure). Report nr. 2005:10 within the BUS-project. RVF, The Swedish Association of Waste Management, Malmö, Sweden.

Savola H. 2006. Biogas systems in Finland and Sweden: Impact of government policies on the diffusion of anaerobic digestion technology. Master thesis, The International Institute for Industrial Environmental Economics, Lund University, Lund, Sweden.

SBGF 2007. Biogasintroduktion (Biogas introduction). http://www.sbgf. info/default.asp?sub=25 (accessed 22 June 2007).

SCB (Swedish Statistics), 2005. Yearbook of agricultural statistics 2005 including food statistics, SCB, Örebro.

Tafdrup S. 2006. Spreadsheet with biomass calculations. Ministry of Energy.

Tike, Information Centre of the Ministry of Agriculture and Forestry in Finland 2006. Yield of the main crops 


\section{Sammendrag}

Nærværende studie har evalueret udviklingen af biogasteknologi i tre Nordiske lande og analyseret effekten af at anvende 9 model energiafgrøder biogasanlæg som eneste substrat eller som tilsats substrat til husdyrgødning. Modelleringen af hver afgrøde er baseret på en total balance for en hektar landbrugsjord. Studiet sammenligner effekten på global opvarmning og energi balancen for de ni afgrøder ved afgasning og kraftvarmeproduktion. Alle energi input i form af gødning, pesticider, diesel, smøreolie har været inkluderet, ligesom process energi I biogasanlægget er medregnet. Det blev besluttet at den anvendte model skulle baseres på et biogassystem, hvor energiafgrøder anvendes som eneste substrat med en gennemsnitlig opholdstid på 40 dage. Resultaterne af energibalancerne af afgrøderne kan imidlertid anvendes i beregninger hvor afgrøden anvendes som co-substrat. Metodologien er den same som har været anvendt $\mathrm{i}$ andre studier, men kun få studier har undersøgt total balancen for en række forskellige afgrøder for 1 hektar landbrugsjord. Ligeledes varierer studierne i system design og afgrænsning. Nærværende studie har ikke inkluderet energi besparelser ved substitution af handelsgødning ved anvendelse af restprodukter efter afgasning som gødning hvorved dette studie underestimerer energi overskuddet men samtidig indregnes transport, lagring og udspredning af restprodukterne ikke og det antages at disse faktorer i de fleste tilfælde ophæver hinanden.

Incitamenter og barrierer for udbygning med biogas varierer mellem de 3 lande og de 9 „model“ afgrøder. Energibalancen og effekten på drihusgasser er ligeledes forskellig I de 3 lande. I Sverige og Danmark var det de samme afgrøder der var mest lovende i forhold til energi overskud og effekt på drivhusgas balancen. I Sverige og Danmark havde jordskokker den højeste score, medens jordskokker I Finland ikke var helt så overbevisende eftersom kun anvendelse af toppen til energi fremstilling blev indregnet. I Finland gav rørgræs endvidere en lovende energibalance. Majs og roer gav et meget højt energi output i alle de 3 Nordiske lande. Generelt var der en god sammenhæng mellem energi balancen og effekten på drivhusgasser i de undersøgte lande.

Baseret på de vægtede parametre kan det konkluderes at de mest lovende afgrøder i de 3 lande er jordskokker, roer majs samt endvidere rørgræs i Finland. Der er imidlertid andre mål end energiproduktion og reduktion af drivhusgasser der kan have lige så stor vigtighed. Vigtige mål som ikke er blevet belyst i dette studie er lavt pesticid forbrug, lav nitratudvaskning, kvælstof fiksering og evne til at øge jordens kulstofpulje. Disse mål opnås bedst ved dyrkning af flerårige afgrøder som kløver, elefantgræs eller rørgræs. 